\title{
Sea urchin barrens as alternative stable states of collapsed kelp ecosystems
}

\author{
Karen Filbee-Dexter*, Robert E. Scheibling \\ Department of Biology, Dalhousie University, Halifax, Nova Scotia B3H 4J1, Canada
}

\begin{abstract}
Sea urchin barrens are benthic communities on rocky subtidal reefs that are dominated by urchins and coralline algae; in the absence of intense herbivory by urchins, these barrens support luxuriant seaweed communities such as kelp beds (or forests). Barrens can extend over 1000s of $\mathrm{km}$ of coastline or occur in small patches (10s to $100 \mathrm{~s}$ of m) within a kelp bed. They are characterized by low primary productivity and low food-web complexity relative to kelp communities and are generally considered a collapsed state of the kelp ecosystem. To assess the stability of sea urchin barrens and potential for return to a kelp-dominated state, we document temporal and spatial patterns of occurrence of barrens along temperate and polar coasts. We examine the various drivers of phase (or regime) shifts in these areas, the threshold levels of urchin abundance that trigger abrupt changes in ecosystem state, and the feedback mechanisms that stabilize each state. Although longitudinal (decadal) studies are limited, we find evidence in several regions that transitions between barrens and kelp beds are characterized by discontinuous phase shifts, with different thresholds for forward (to barrens) and reverse (to kelp beds) shifts, in accordance with alternative stable-state dynamics. In other areas, barrens may reflect regime shifts associated with large-scale oceanographic changes. Accelerating climate change and increasing anthropogenic impacts play important roles in altering alternative stable-state dynamics and triggering phase shifts. Recovery of the kelp state may be possible through management or remediation measures, but this necessitates a clear understanding of the thresholds and stabilizing factors for a given system.
\end{abstract}

KEY WORDS: Sea urchin barrens - Kelp beds . Alternative stable states $\cdot$ Phase shifts

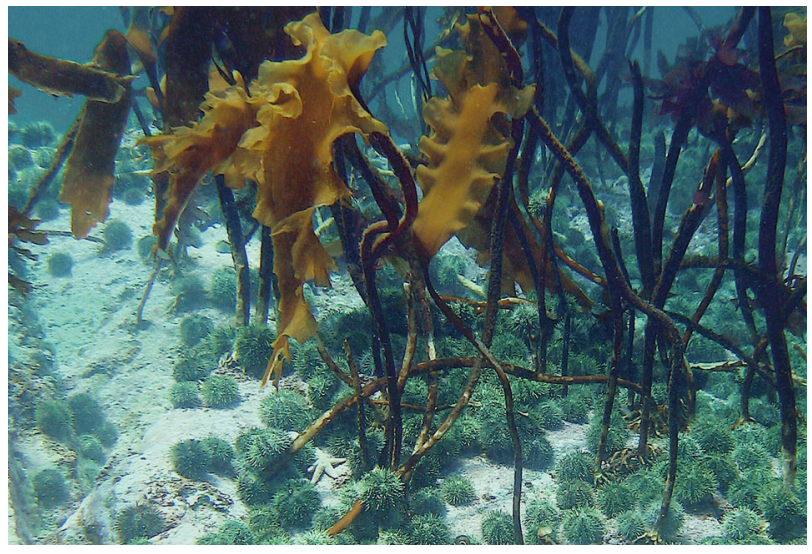

Sea urchins Strongylocentrotus droebachiensis graze along the edge of a kelp bed, creating a barren.

Photo: Robert Scheibling

\section{INTRODUCTION}

Sea urchin barrens are benthic communities that are dominated by herbivorous sea urchins and coralline red algae on rocky reefs devoid of seaweed (Pearse et al. 1970) (Fig. 1). Barrens generally occur in regions that can support kelp beds (or forests), which are highly productive and provide habitat and food for many ecologically and commercially important fish and invertebrate species (Konar \& Estes 2003, Ling 2008, Bonaviri et al. 2012). Over the last 4 decades, transitions between kelp beds and sea urchin barrens have been widely reported along temperate coastlines globally (Sala et al. 1998, Pinnegar et al. 2000, Steneck et al. 2002). These transitions, termed phase shifts, generally occur when a change in sea urchin grazing intensity moves the sys- 

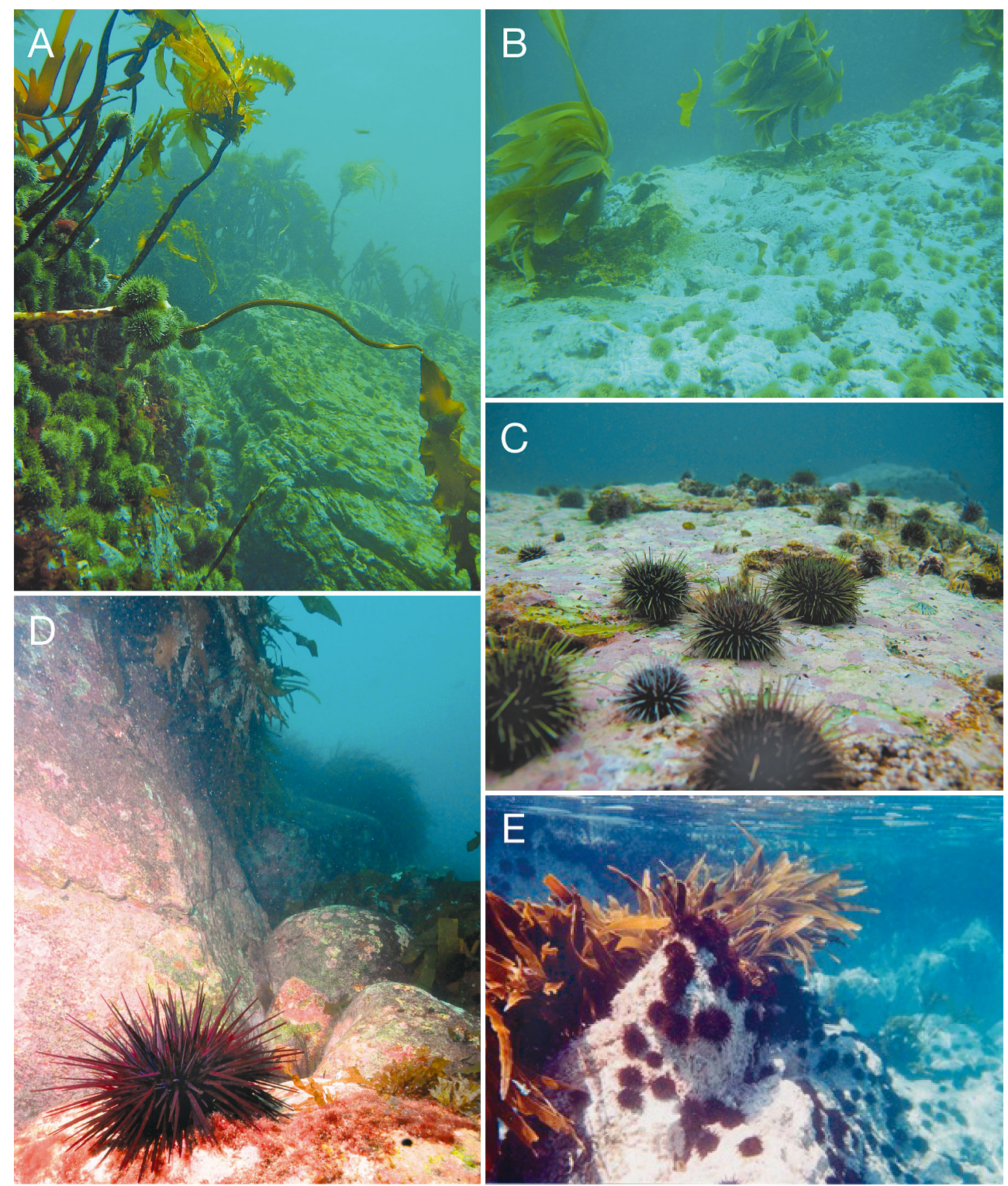

Fig. 1. (A) Destructive grazing front of sea urchins Strongylocentrotus droebachiensis advancing into a kelp bed near Halifax, Nova Scotia, Canada. Photo credit: R. E. Scheibling. (B) Extensive urchin (S. polyacanthus) barrens in the Aleutian Islands, USA. Photo credit: B. Konar. (C) Urchins S. droebachiensis on scoured coralline algae in barrens in Norway. Photo credit: C. W. Fagerli. (D) Range-expanding urchin Centrostephanus rodgersii forming patchy barrens in a kelp bed in southeast Tasmania. Photo credit: S. D. Ling. (E) S. nudus grazing a kelp bed in Japan. Photo credit: D. Fujita

tem from one stable (i.e. robust to relatively small perturbations) community state to another (Lawrence 1975, Steneck et al. 2002). Sea urchin barrens have much lower primary productivity and habitat structural complexity than kelp beds and consequently can be considered a collapse of the kelp state (Simenstad et al. 1978, Chapman \& Johnson 1990, Sivertsen 1996, Graham 2004, Christie et al. 2009). Since kelp beds are key components of coastal ecosystems that provide important services to resident communities (Mann 1973, Levin 1994, Krumhansl
\& Scheibling 2012), understanding the factors that cause phase shifts to urchin barrens, and that enable kelp beds to recover, is crucial for the proper management of these ecosystems.

Of particular concern to managers is the possibility that sea urchin barrens are a stable state of the subtidal ecosystem, maintained by various feedback mechanisms that prevent recovery of the kelpdominated state after the initial driver of the phase shift has been relaxed or reversed (Lauzon-Guay et al. 2009, Ling et al. 2009). This type of transition is 
A. Discontinuous phase shift

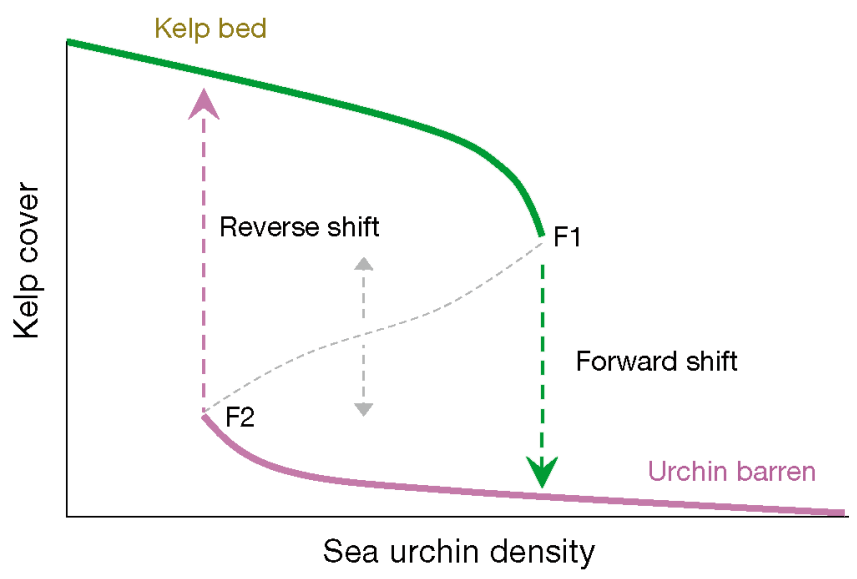

B. Continuous phase shift

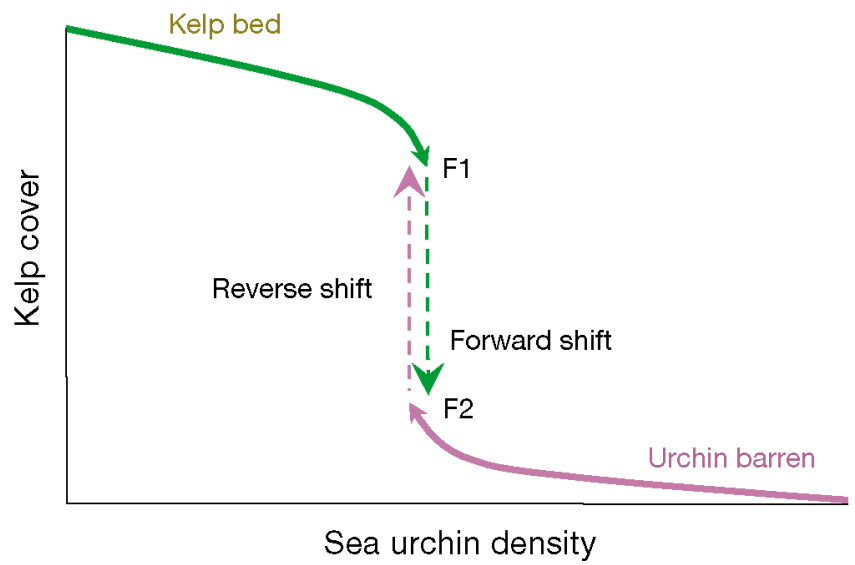

Fig. 2. (A) Discontinuous phase shift. As a kelp ecosystem (upper green path) approaches the threshold sea urchin density F1, a small increase in density will forward-shift the kelp-bed state to a barrens state. Once barrens have formed, a reverse shift (lower pink path) back to the kelp-bed state occurs when sea urchin density is reduced below the F2 threshold. The difference between F1 and F2 thresholds indicates the strength of hysteresis in the system. The dashed gray line represents the region of instability between the 2 alternative stable states. (B) Continuous phase shift. The forward shift threshold F1 and reverse shift threshold F2 occur at the same sea urchin density. The barren state only persists with high urchin densities and the kelp state immediately recovers when densities are reduced. Redrawn from Scheffer et al. (2001)

termed a discontinuous phase shift (Fig. 2A) and characterizes an alternative stable-state system (Lewontin 1969, Scheffer et al. 2001, Collie et al. 2004, Mumby et al. 2007, Fung et al. 2011). It is discontinuous because the threshold for the forward shift to the barrens state is at a different level than the threshold for the reverse shift back to the kelp state. In contrast, the forward and reverse transitions of a continuous phase shift (Fig. 2B) occur around the same threshold level (Petraitis \& Dudgeon 2004). There is mounting evidence from marine systems (such as kelp beds, seagrass beds and coral reefs) that collapse to less productive or structurally complex states occurs at a critical threshold of a forcing variable (Sutherland 1974, Scheffer et al. 2001, Petraitis \& Dudgeon 2004, Casini et al. 2009). However, few studies have conclusively documented alternative stable-state dynamics (Knowlton 2004), and these have focused mainly on tropical coral reefs (Jackson 1997, Mumby et al. 2007, Dudgeon et al. 2010, Fung et al. 2011).

Despite compelling evidence of discontinuous phase shifts to sea urchin barrens for several regions, including Alaska, USA (Estes et al. 1998), Nova Scotia, Canada (Lauzon-Guay et al. 2009), and Tasmania, Australia (Ling et al. 2009), the existence of barrens as a true alternative stable state of kelp ecosystems remains controversial. Petraitis \& Dudgeon (2004) argue that inadequate information on the mechanisms that create and stabilize kelp beds and urchin barrens precludes their classification as alternative stable-state systems but that they remain strong candidates for this designation. Other explanations for large-scale shifts between kelp beds and barrens are that they represent continuous phase shifts between states, most likely caused by ongoing anthropogenic impact (Connell \& Sousa 1983, Petraitis \& Dudgeon 2004), or that they are part of a larger oceanic regime shift to coralline-dominated barrens (Dayton et al. 1998, Lees et al. 2006, Wernberg et al. 2011). If shifts to sea urchin barrens are part of a regime shift, these transitions will likely involve an abrupt, long-term (decadal) change in oceanographic conditions occurring at large spatial scales and impacting multiple trophic levels (De Young et al. 2004, Lees et al. 2006).

In a comprehensive review of sea urchin grazing behaviour on kelps and other macroalgae, Lawrence (1975) summarized existing records of the distribution of sea urchin-dominated barren grounds. Steneck et al. (2002) reviewed the literature on kelp ecosystem collapses in temperate and boreal regions worldwide, including transitions to sea urchin barrens and possible forcing variables of phase shifts. Ecosystem-specific reviews of alternations between kelp and barrens states also exist for Chile (Vásquez \& Buschmann 1997), Maine, USA (Steneck et al. 2013), Nova Scotia (Scheibling et al. in press) and the Northeast Atlantic (Norderhaug \& Christie 2009). Here, we document the extent and history of occurrence of sea urchin barrens amid kelp-bed ecosystems worldwide to compile evidence on the nature 
of phase shifts and potential for alternative stable states. We include several canopy-forming brown algal communities (of the genera Sargassum and Cystoseira) in the Mediterranean in our survey, as these macroalgae are functionally and taxonomically similar to kelps (Round 1967) and offer further insights into the formation of sea urchin barrens. We begin by briefly reviewing the theoretical framework of alternative stable-state dynamics and the associated terminology, which has been used inconsistently and often inaccurately in the large and growing body of literature on the subject. We then examine the drivers of phase shifts between kelp beds and barrens and the feedback mechanisms that stabilize each community state. Lastly, we examine shifts to sea urchin barrens in the context of changing marine environments, and investigate the implications of a collapse in kelp ecosystems for marine management and conservation.

\section{ALTERNATIVE STABLE STATES}

The concept of alternative stable states had its theoretical underpinnings in the models of Lewontin (1969), Sutherland (1974) and May (1977). Peterson (1984) provided evidence of state shifts among naturally occurring communities and identified the concept of stability as a critical aspect of alternative stable-state theory. He proposed a simple criterion as evidence of alternative stable states: different selfreplacing communities can potentially dominate a given site. Connell \& Sousa (1983) presented stricter criteria that required each state to exist at a longterm stable equilibrium (longer than 1 complete turnover of the dominant species) and the system to return to this point following a relatively small perturbation or disturbance, such as a fluctuation in a species' density or a storm event. They suggested that long-term (decadal) studies are required to distinguish alternative stable states. Additional conditions for stability are that each state must persist in the absence of the perturbation(s) that triggered the transition and be maintained by feedbacks that strengthen a current state (Petraitis \& Latham 1999).

When this theoretical framework is applied to natural systems, this definition of stability becomes critical (Grimm \& Wissel 1997). The requirement that the state must exist for the lifespan of the dominant species under similar environmental conditions can be difficult to assess because (1) it requires long-term research (e.g. over $100 \mathrm{yr}$ for the red sea urchin Strongylocentrotus franciscanus; Ebert \& Southon
2003), (2) it does not allow for natural variation in environmental conditions, and (3) selection of dominants can be subjective in systems with many abundant species. For this reason, our review focuses on the stabilizing mechanisms and feedback loops that create domains of stability, instead of defining stability as the elapsed time in a state. Here, we define a stable state as a distinct community assemblage with feedback mechanisms that, under normal environmental conditions, confer resistance or resilience of the community to relatively small perturbations (see Table 1 for a glossary of ecological terms).

An important property of alternative stable states is hysteresis (Scheffer et al. 2001). Hysteresis occurs when an alternative state persists after the driver of the transition is relaxed or reversed. Hysteresis is created by various stabilizing mechanisms that inhibit return to the previous state. Therefore, for a kelp bed to re-establish in the barrens state, sea urchin density (a proxy for herbivory) would have to decrease well below the threshold density that caused the initial shift to barrens (Breen \& Mann 1976, Ling et al. 2009) (Fig. 2A). The difference between thresholds for shifts in either direction determines the degree of hysteresis and the range of sea urchin densities that can occur in either a kelp or a barrens state. Transitions between 2 states without hysteresis are continuous phase shifts and are readily reversed by relaxing the forcing variable to the threshold level that caused the shift (Petraitis \& Dudgeon 2004) (Fig. 2B). For example, phase shifts triggered by anthropogenic drivers may result in an ecosystem state that is only stabilized by the presence of continuing anthropogenic perturbation, such that the original state is recovered when human impact ceases (Knowlton 2004).

From a modelling perspective, a system can undergo a phase shift to a new state when a change in either state variables or system parameters passes a threshold where stabilizing mechanisms maintaining the original state are overcome (Beisner et al. 2003) (Fig. 3). State variables are system quantities (e.g. kelp biomass, abundances of urchins or their predators, larval supply) that change quickly in response to feedback mechanisms within the ecosystem. System parameters are measures that describe the behaviour of state variables and their interactions (e.g. grazing rate, per capita predation, settlement rate). Parameters can either change independently of state variables or be subject to slow feedback mechanisms originating within the system state (Table 1). A phase shift due to a strong perturbation or gradual change in state variables can shift the community from one 
Table 1. Glossary of ecological terms, with examples from kelp bed and urchin barrens community states

\begin{tabular}{|c|c|c|}
\hline Term & Definition & Examples \\
\hline $\begin{array}{l}\text { Alternative stable- } \\
\text { state ecosystem }\end{array}$ & $\begin{array}{l}\text { An ecosystem that experiences discontinuous } \\
\text { phase shifts, meaning it can exist in two stable } \\
\text { states under the same environmental conditions. }\end{array}$ & Sea urchin barrens and kelp beds. \\
\hline $\begin{array}{l}\text { Continuous phase } \\
\text { shift }\end{array}$ & $\begin{array}{l}\text { Transition from one ecosystem state to another } \\
\text { where the threshold for the forward shift is at the } \\
\text { same level as the threshold for the reverse shift } \\
\text { back to the previous state. }\end{array}$ & $\begin{array}{l}\text { A shift to barrens, where the kelp bed can re- } \\
\text { establish when urchin grazing intensity decreases } \\
\text { to the threshold density triggering the initial shift. }\end{array}$ \\
\hline $\begin{array}{l}\text { Discontinuous } \\
\text { phase shift }\end{array}$ & $\begin{array}{l}\text { Transition from one ecosystem state to another } \\
\text { where the threshold for the forward shift is at a } \\
\text { different level than the threshold for the reverse } \\
\text { shift back to the previous state. }\end{array}$ & $\begin{array}{l}\text { A shift to barrens, where the kelp bed does not re- } \\
\text { establish until urchin grazing intensity decreases } \\
\text { well below the threshold density triggering the } \\
\text { initial shift. }\end{array}$ \\
\hline Driver & $\begin{array}{l}\text { A forcing agent that causes a change in state } \\
\text { variable(s) or parameter(s) that results in a phase } \\
\text { shift. }\end{array}$ & $\begin{array}{l}\text { Overfishing or recovery of urchin predators, } \\
\text { urchin recruitment pulse, disease outbreak, storm } \\
\text { event or loss of kelp that results in an increase or } \\
\text { decrease in sea urchin grazing intensity. }\end{array}$ \\
\hline Ecosystem state & $\begin{array}{l}\text { The arrangement of species or populations } \\
\text { within an ecosystem and their interactions with } \\
\text { the physical environment. }\end{array}$ & $\begin{array}{l}\text { Abundances of macroalgal species, coralline algae } \\
\text { and sea urchins, as well as the 3-dimensional } \\
\text { structure of the kelp bed and its associated } \\
\text { properties. }\end{array}$ \\
\hline Regime shift & $\begin{array}{l}\text { Changes in oceanographic processes and marine } \\
\text { system functioning that are persistent, occur at a } \\
\text { large spatial scale and over multiple trophic levels, } \\
\text { and are related to climate oscillations or change. }\end{array}$ & $\begin{array}{l}\text { Shifts to barrens caused by El Niño-Southern } \\
\text { Oscillation events in California and Chile, and } \\
\text { southern intrusion of the East Australian Current } \\
\text { off Tasmania. }\end{array}$ \\
\hline Resilience & $\begin{array}{l}\text { The ability of a community to return to an equi- } \\
\text { librium state after a disturbance or perturbation. }\end{array}$ & $\begin{array}{l}\text { Regeneration of a kelp bed after a defoliation } \\
\text { event. Return to a barrens state after a partial die- } \\
\text { off of sea urchins or a temporary cessation in their } \\
\text { foraging activity due to strong wave action. }\end{array}$ \\
\hline Stability & $\begin{array}{l}\text { The result of various feedback mechanisms that, } \\
\text { under normal environmental conditions, enable } \\
\text { a community to persist in a given state, and } \\
\text { resist or be resilient to small perturbations. }\end{array}$ & $\begin{array}{l}\text { A kelp bed that stays essentially unchanged } \\
\text { under constant environmental conditions, is } \\
\text { resistant to increases in urchin density, and is } \\
\text { resilient to small perturbations such as canopy } \\
\text { loss, temperature change or predator decline. }\end{array}$ \\
\hline State parameter & $\begin{array}{l}\text { Measure that governs the behaviour of state } \\
\text { variables and how they interact in an ecosystem. }\end{array}$ & $\begin{array}{l}\text { Urchin grazing rate, kelp growth rate, recruitment } \\
\text { rates, per capita predation rates. These measures } \\
\text { can vary with changes in ocean currents, ocean } \\
\text { temperature and large-scale overfishing. }\end{array}$ \\
\hline State variable & $\begin{array}{l}\text { Property of an ecosystem that responds to } \\
\text { changes in parameters. }\end{array}$ & $\begin{array}{l}\text { Kelp biomass, sea urchin density, predator abun- } \\
\text { dance, larval abundance. }\end{array}$ \\
\hline
\end{tabular}

state to another without affecting the stability landscape or parameters of the system. In this type of transition, the system can exist in 2 or more community states under the same set of environmental conditions. Conversely, a large change in system parameters will alter the behaviour of the state variables, which could destabilize a community and shift it to another domain of stability. Some examples of changes in parameters that have caused shifts between kelp beds and coralline barrens are the in- creased mortality rate of sea urchins due to disease outbreaks associated with warming ocean temperatures and storm severity in Nova Scotia (Scheibling \& Lauzon-Guay 2010), the increased survival rate of sea urchins due to changes in ocean currents in Tasmania (Ling 2008), and the change in crab predation rates due to large-scale overfishing of groundfish in Maine (Steneck et al. 2004). It is difficult to conceive of a marine system existing under a relatively constant set of parameters for decades, particularly when seasonal 


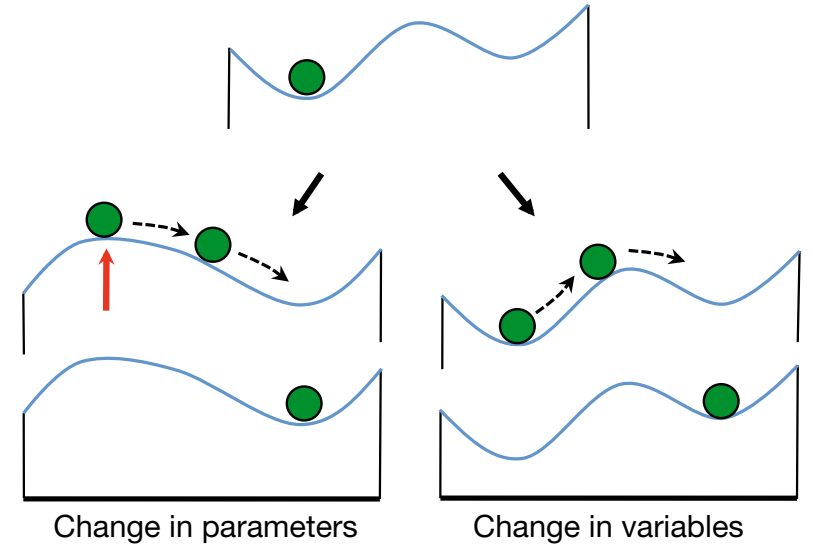

Fig. 3. Ball-in-cup diagram of alternative stable states. A ball represents a particular community state that exists on a landscape representing all possible states ( 2 states are considered for simplicity). Cups represent domains of attraction within that landscape. Each ball is continually 'vibrating' within these domains in response to seasonal cycles and natural variability in the ecosystem. The depth of a basin approximates resilience to these natural variations and small perturbations in the environment. Domains of attraction are also modified as system parameters change over time. The ecosystem can shift from one state to another (as represented by displacement of the ball) by either a change in state variables that moves the ball to a new domain of attraction or a change in state parameters that alters the landscape. Top diagram: initial condition with a community in 1 of 2 possible states; red vertical arrow: change in domains of attraction; dashed black arrows: shifts from one domain of attraction to another. Redrawn from Beisner et al. (2003)

cycles, natural variability and anthropogenic impacts are continually changing the community landscape. Therefore, domains of stability represent dynamic community assemblages that are constantly being modified as system parameters change over time.

\section{KELP DISTRIBUTION AND ECOLOGY}

Kelps are large brown seaweeds (class Phaeophyceae, order Laminariales) that inhabit temperate or polar coastal regions throughout the world (Steneck \& Dethier 1994, Dayton et al. 1999, Steneck et al. 2002) (Fig. 4, Appendix). They exhibit 3 basic morphologies that characterize kelp stands as forests (stipitate and canopy-forming kelps, with fronds suspended above the seabed) or beds (prostrate forms, with fronds lying on or near the seabed) (Steneck et al. 2002). Canopy kelps (e.g. Macrocystis pyrifera, Nereocystis leutkeana, Ecklonia maxima, and Alaria fistulosa) can extend to the ocean surface, forming extensive forests along the western coasts of North and South America. They also are scattered throughout South Africa, Southern Australia and New Zea- land. Stipitate kelps (e.g. Laminaria japonica, Lessonia trabeculata and Ecklonia radiata) form midwater stands extending from the Japan Sea across the North Pacific to California, USA. Prostrate kelps (e.g. Saccharina latissima and Laminaria digitata) form low-lying kelp beds throughout much of the North Atlantic and are the dominant forms in Greenland, Norway and along the east coast of Canada to Maine. (For simplicity, here we generally designate kelp communities as beds, unless the distinction as forest is important.)

Kelps typically live a maximum of 25 yr (Steneck \& Dethier 1994) and grow best in high-nutrient, coldwater areas (Tegner et al. 1996). They have high rates of primary production (Dayton 1985) and support a variety of herbivorous and detritivorous species that graze attached or drift kelp (Duggins et al. 1989, Krumhansl \& Scheibling 2012). Kelps also are host to various suspension feeders and micropredators (Ling 2008) and serve as important nursery habitats for many fish (Bodkin 1988, Levin 1994). Periods of high recruitment and primary productivity enable kelp beds to rapidly increase in biomass, while periods of severe storm activity (Filbee-Dexter \& Scheibling 2012), intensive grazing (Vadas \& Steneck 1988), low light or nutrient conditions (Dayton 1985, Tegner \& Dayton 1991, Tegner et al. 1996), and warm water (Dayton et al. 1999) erode or defoliate kelp beds.

\section{GLOBAL DISTRIBUTION OF SEA URCHIN BARRENS}

Open clearings that are denuded of seaweeds and have high densities of sea urchins have been observed in shallow rocky habitats worldwide (Table 2, Fig. 4). The spatial extent of these barrens can range from 1000s of $\mathrm{km}$ of coastline to small patches (100s of $\mathrm{m}$ in extent) within a kelp bed (Table 2). Urchin barrens are dominated by invertebrate species, mainly sea urchins, but also sea stars, mussels and brittle stars. They are devoid of fleshy and filamentous algae and are primarily covered by encrusting coralline algae of low nutritional value. Coastal areas dominated by sea urchin barrens typically retain some localized or spatially limited stands of kelp and other seaweeds. For example, kelps have a refuge from urchin grazing in wave-swept shallow waters without sea ice (Lauzon-Guay \& Scheibling 2007a), and form small patches throughout urchin barrens in some areas (Vásquez \& Buschmann 1997, Konar 2000).

Depending largely on the time span and intensity of research in different regions, sea urchin barrens 


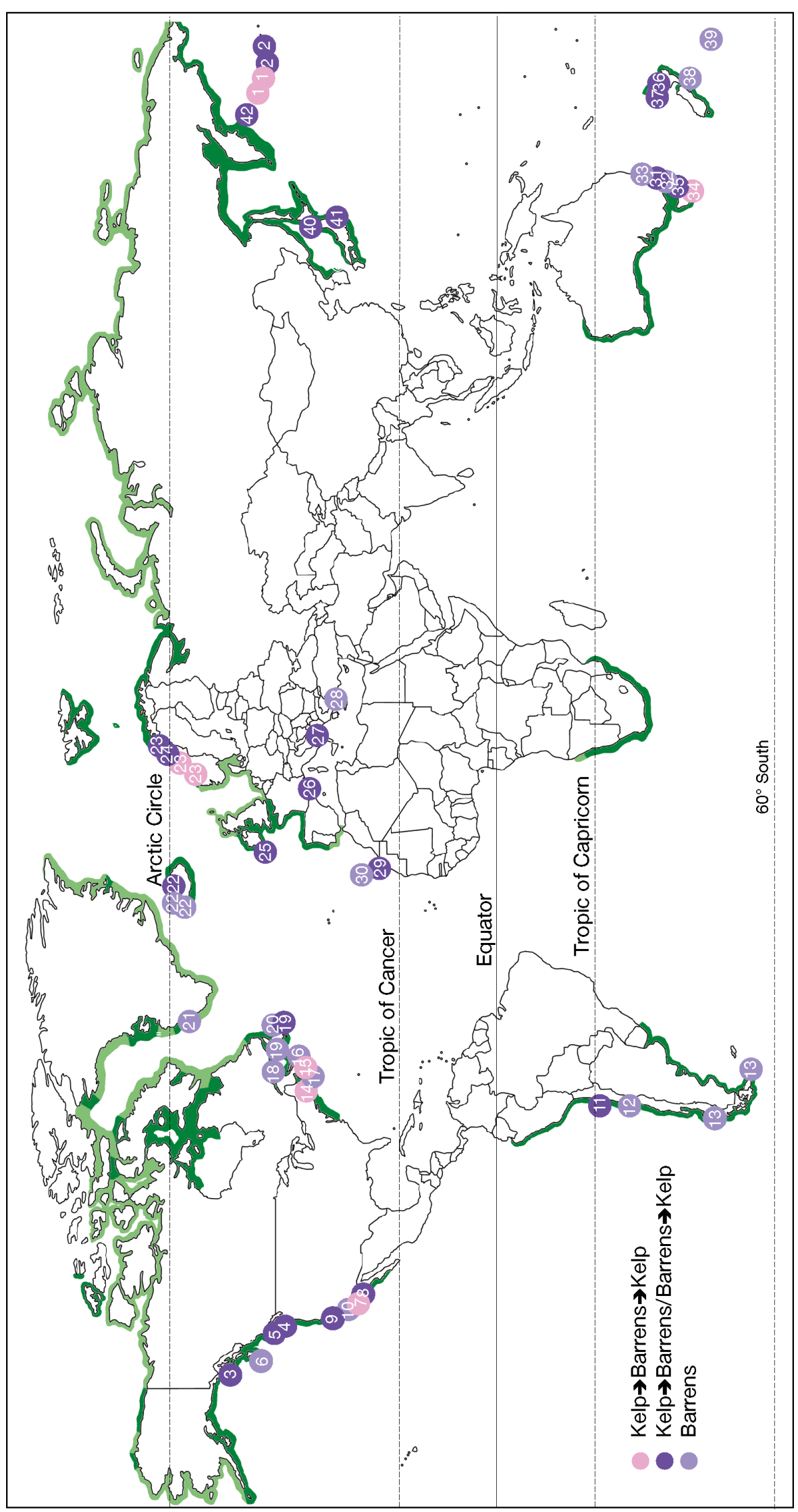

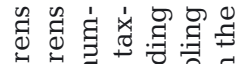

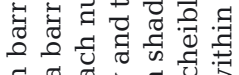

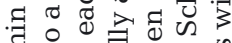

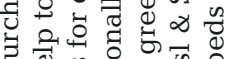

政

क व

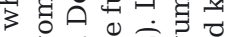

品宁宁客起

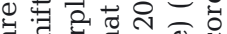

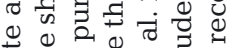

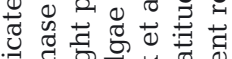

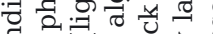

의의

ه

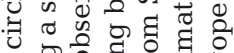

o

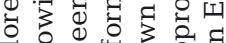

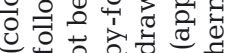

的

政

하의

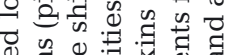

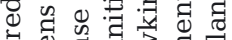

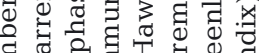

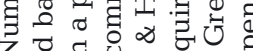

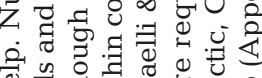

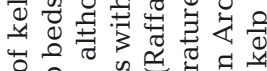

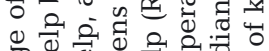

急

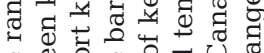

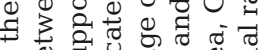

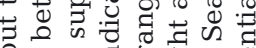

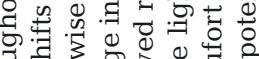

5 .

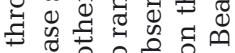

웡

列

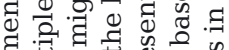

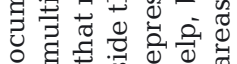

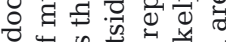

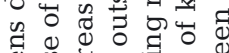

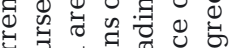

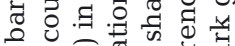

응 क्र

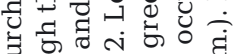

o $\overline{0}$ 윰

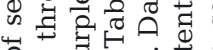

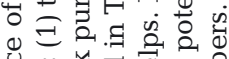

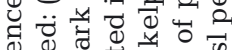

웝

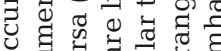

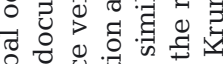

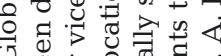

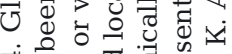

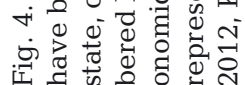




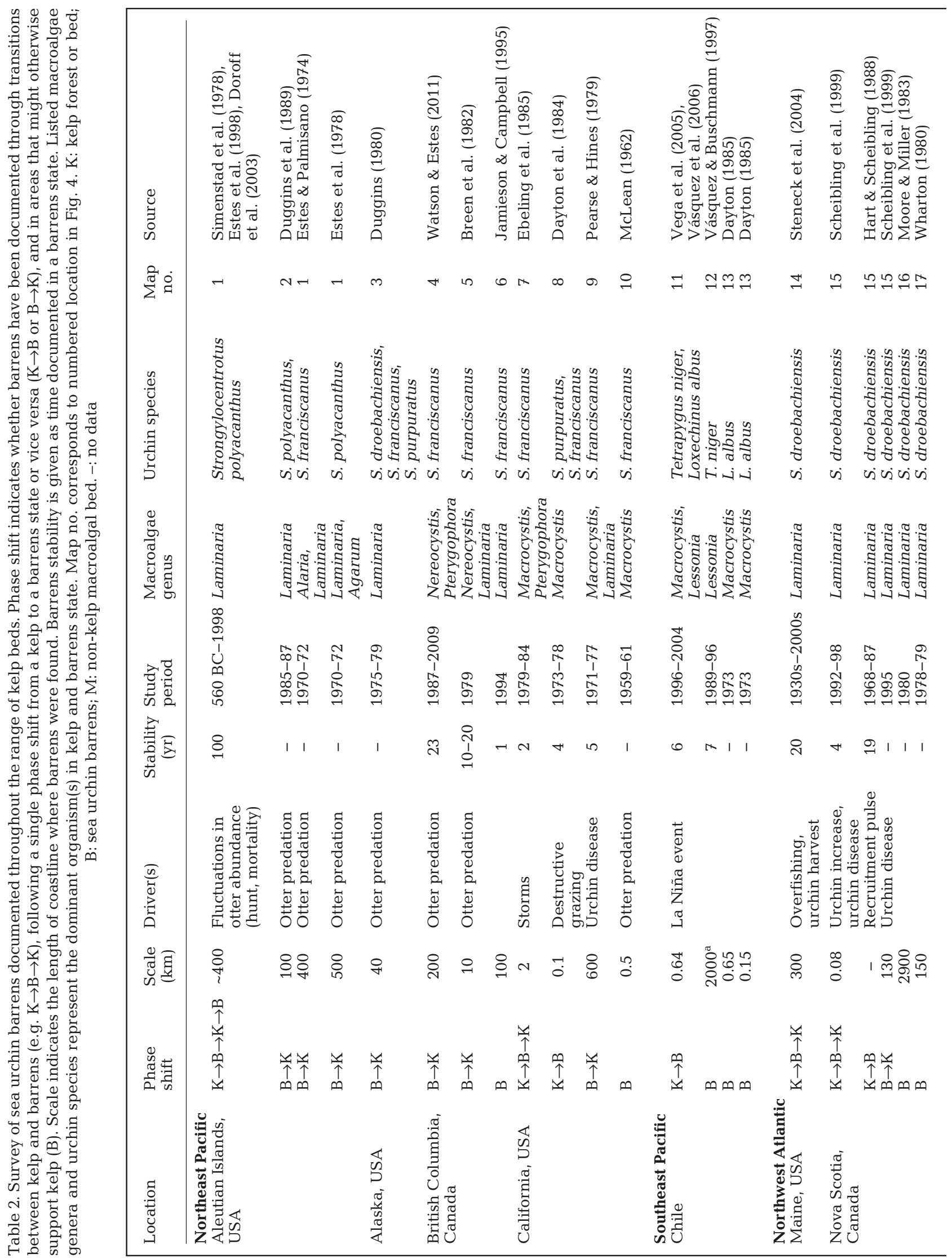




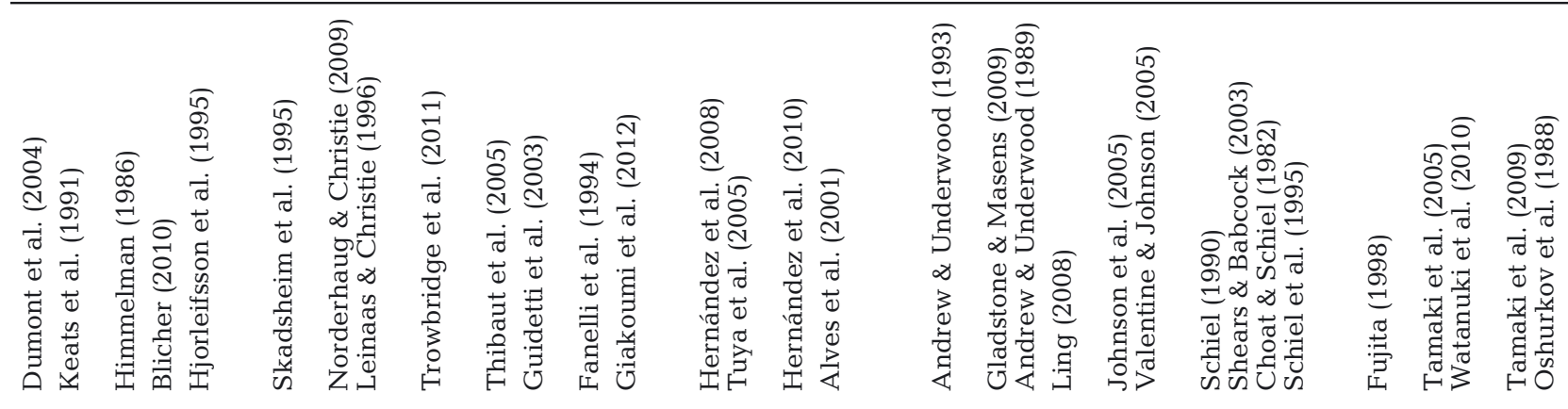

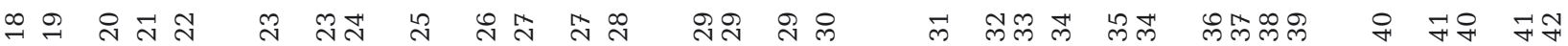

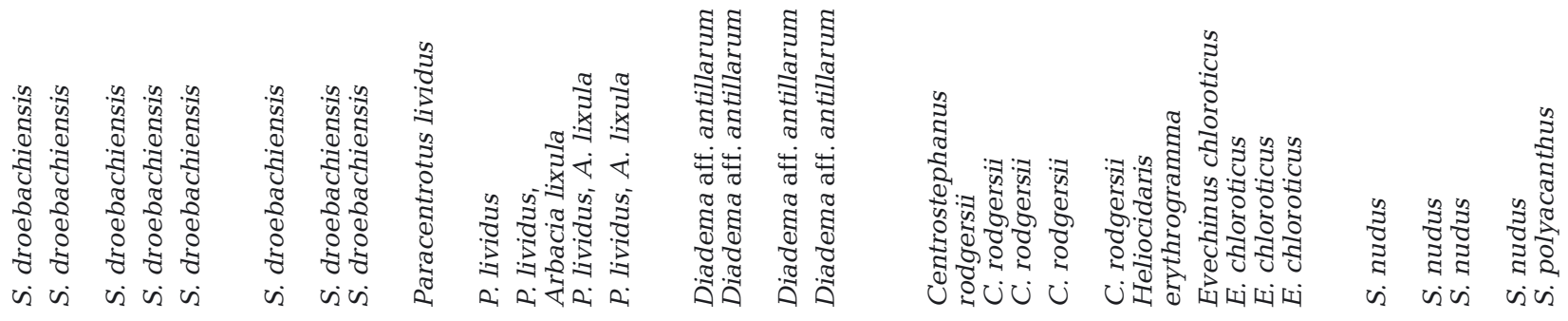

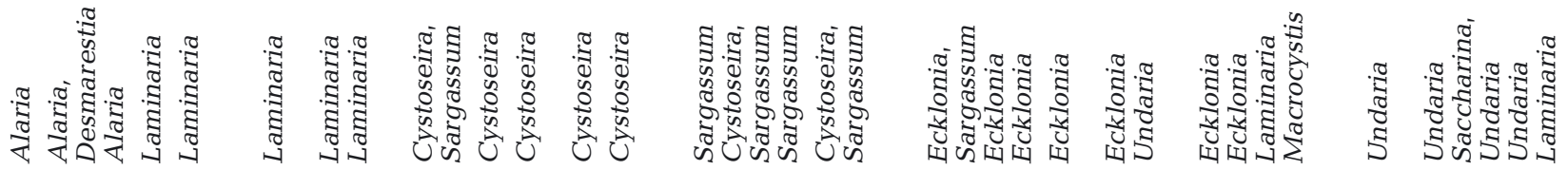

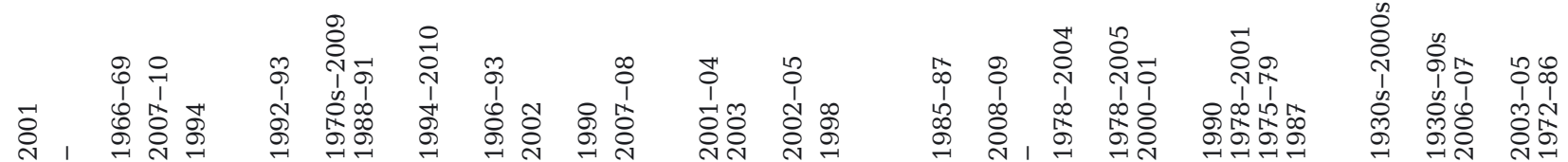

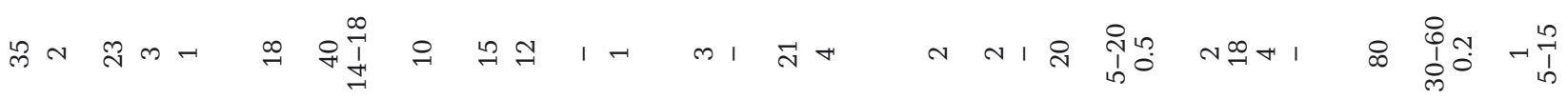

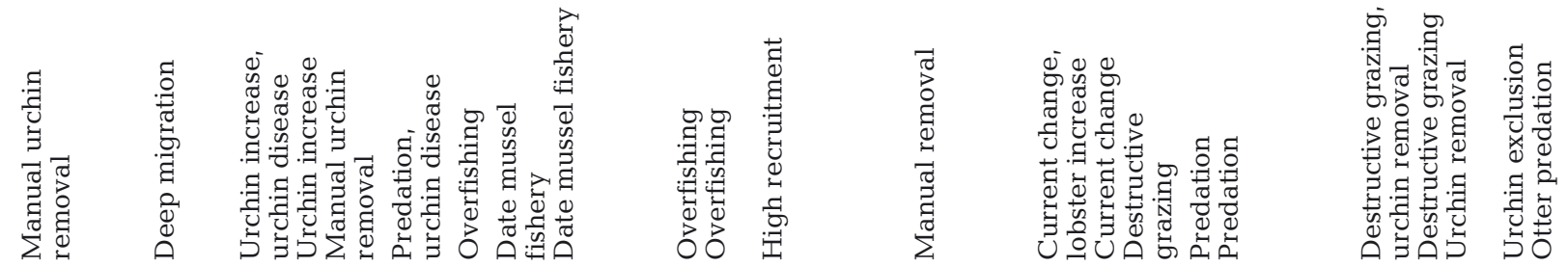

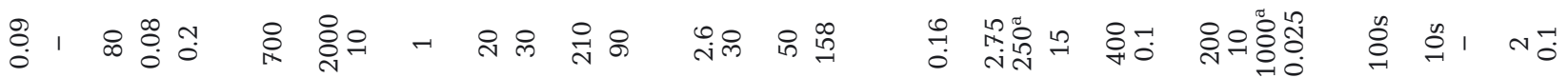

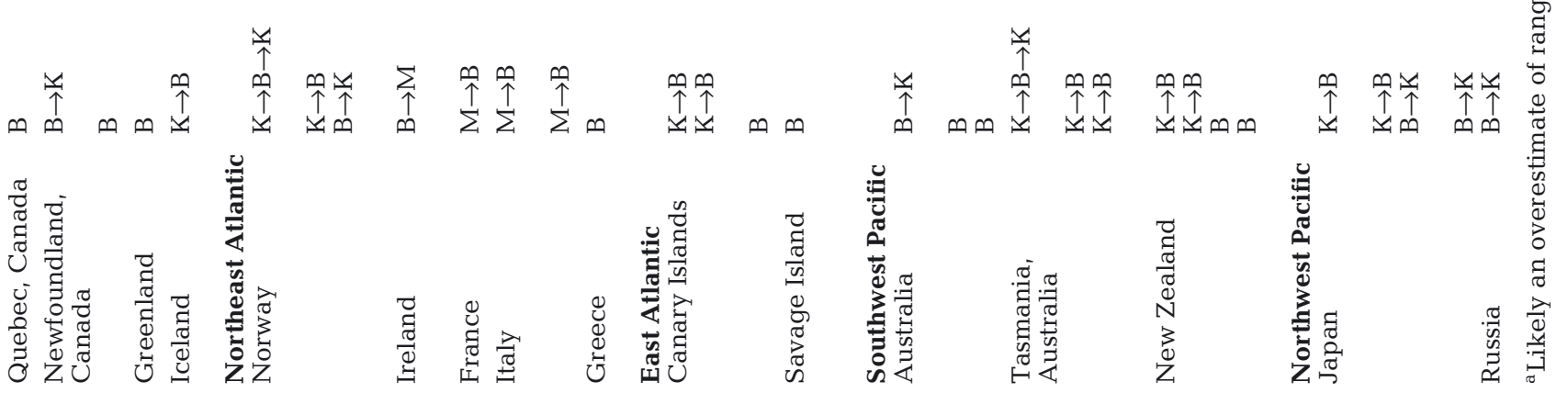


have been documented under 3 types of conditions: (1) through multiple phase shifts between kelp beds and urchin barrens, (2) following a single phase shift from a kelp to a barrens state, or vice versa, and (3) in areas that might otherwise support kelp, although a phase shift has not been observed. In what follows, we survey the occurrence of sea urchin barrens throughout the global range of kelps (and some other canopy-forming brown algae) and consider the drivers of phase shifts that have led to barrens.

\section{Barrens in regions with documented multiple phase shifts}

Ecosystems where multiple shifts between kelp and barrens states have been documented provide important information on the drivers of these transitions and the stability of each state. Drivers of changes in urchin grazing intensity vary between these systems, but grazing typically increases after periods of high urchin recruitment and drift kelp shortage, and decreases with predation, overfishing and disease (Fig. 5). The first evidence of kelp beds alternating with sea urchin barrens comes from the Aleutian Islands in the Northwest Pacific, where sea otters are major predators of the sea urchin Strongylocentrotus polyacanthus (Fig. 5A). Early European explorers described subtidal areas in the Aleutians as a lush kelp forest with abundant sea otter populations (Simenstad et al. 1978). By the 1800s, extensive hunting for the fur trade had decimated sea otter populations and caused the sea urchin population to increase and destructively graze kelp forests (Simenstad et al. 1978). This shifted the system to stable coralline barrens. Legal protection of sea otters in 1911 enabled sea otter populations to recover and reduce sea urchin densities to a level where kelp forests could re-establish (Estes \& Palmisano 1974). The recovered kelp forests (Alaria fistulos and Laminaria spp.) were maintained for decades, until otter populations began to sharply decline due to predation by killer whales in the 1990s (Estes et al. 1998). This enabled sea urchin populations to increase once again and destructively graze kelp, leading to the formation of barrens across most of the Aleutian archipelago (Doroff et al. 2003). The Aleutians also provide a unique historical record of the state of the coastal ecosystem based on the contents of aboriginal middens (Simenstad et al. 1978). High abundances of fish and sea otter remains in middens from 580 BC suggest a kelp forest state, whereas high abundances of sea urchins and limpets in middens from 80 BC suggest a barrens state, providing evidence of localized transitions from kelp forests to coralline algal barrens over 2000 yr ago, possibly associated with aboriginal overharvest of sea urchin predators (Simenstad et al. 1978).

In California, there is similar archeological evidence of short-lived, localized shifts from giant kelp Macrocystis pyrifera forests to barrens thousands of years ago (Erlandson et al. 1996). Phase shifts from kelp forests to sea urchin barrens were recorded in California in the 1950s (Dayton et al. 1984) and were attributed mainly to the fishery-induced collapse of spiny lobster and sheepshead fish populations (Dayton et al. 1998), predators of sea urchins that filled the functional role of sea otters after the fur trade had eliminated them in the 1800s (Fig. 5B). These sea urchin barrens persisted in California until the 1960s, when the reintroduction of sea otters led to reinstatement of kelp forests in some areas (McLean 1962, Ebert 1968). However, widespread kelp forest recovery did not occur until the mid-1970s, when a fishery opened for red sea urchins Strongylocentrotus franciscanus (Dayton et al. 1998). In 1988, localized phase shifts to urchin barrens were documented following a winter storm event, and they persisted until sea urchin disease outbreaks in 1991 enabled kelp forest recovery (Dayton et al. 1992, Tegner et al. 1997). Presently, kelp forests dominate much of the Californian coast, although patchy urchin barrens occur amid these forests, and kelp only occupies a third of the range measured in 1911 (Tegner et al. 1996).

Shifts between kelp forests and barrens also have been associated with changing oceanographic conditions due to the El Niño-Southern Oscillation. In California, El Niño events in 1957-1959, 1982-1984 and 1992-1993 disrupted upwelling and brought warm, nutrient-depleted waters to coastal regions (Tegner \& Dayton 1991, Dayton et al. 1998, Dayton et al. 1999). This reduced kelp biomass, and in some regions created temporary barrens that were recolonized by kelps during La Niña conditions (Tegner \& Dayton 1987, Tegner et al. 1997). Conversely, in an $8 \mathrm{yr}$ study of a kelp forest (Macrocystis integrifolia and Lessonia trabeculata) in northern Chile, Vásquez et al. (2006) documented a 3-fold increase in recruitment of sea urchins Tetrapygus niger and a sharp decline of kelp cover during a La Niña event in 1999. This created a barrens state that was stable for 4 yr until the kelp forest re-established in 2003.

In the Northwest Atlantic, kelp beds (Saccharina latissima) in Maine, have exhibited 3 distinct phases in the last century (Steneck et al. 2004) (Fig. 5C). The historical state was dominated by large predatory 


\section{A. Aleutian islands}

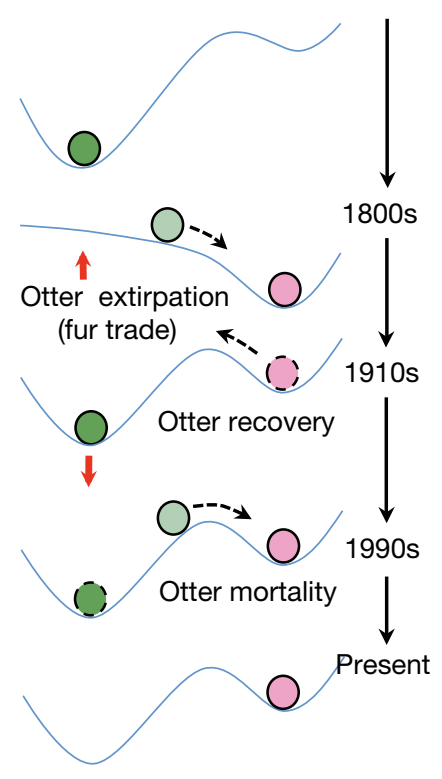

D. Nova Scotia

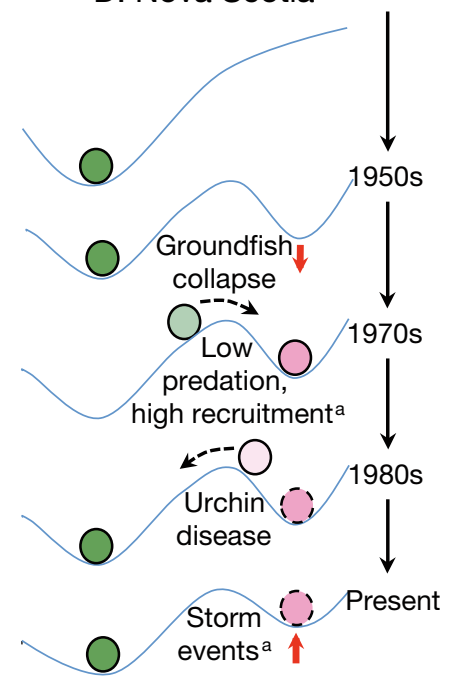

B. Central California

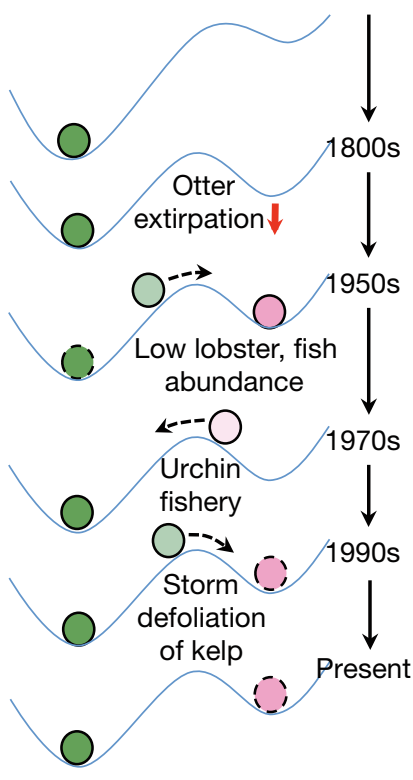

E. Norway

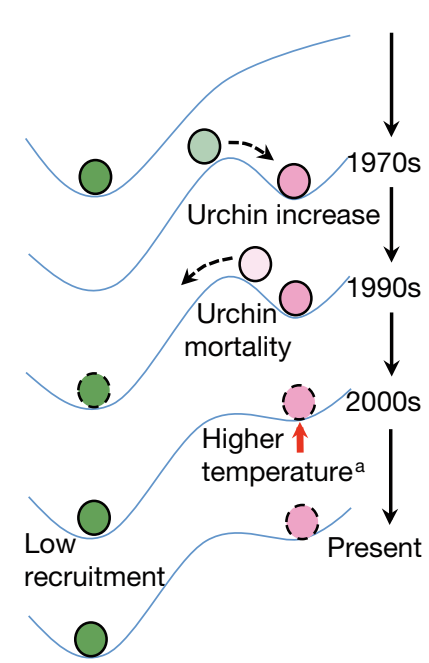

\section{Maine}

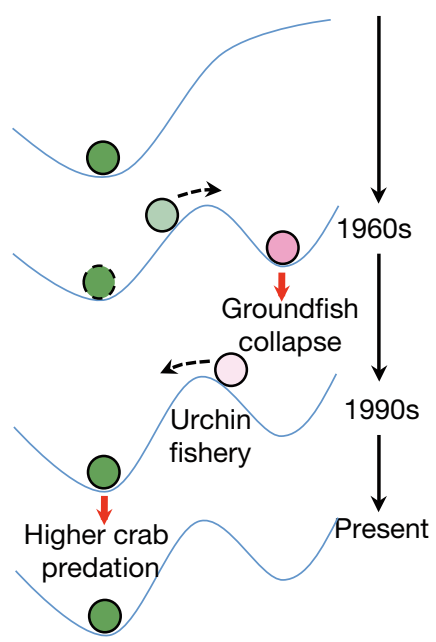

\section{F. Tasmania}

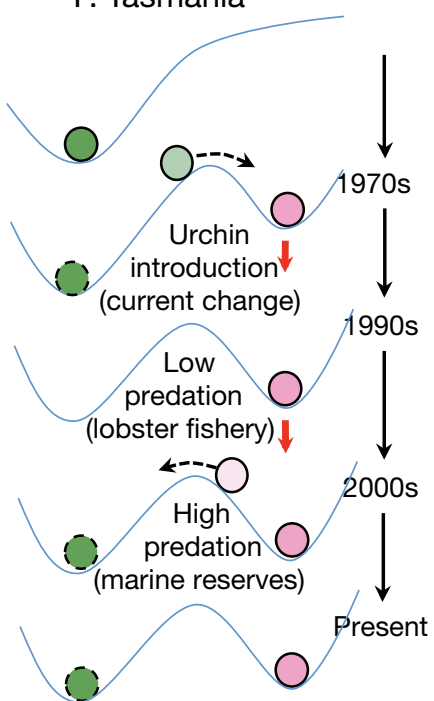

Fig. 5. Ball-in-cup diagrams representing phase shifts between kelp beds and sea urchin barrens in 6 regions: (A) Aleutian Islands, USA, (B) Central California, USA, (C) Maine, USA, (D) Nova Scotia, Canada, (E) Norway and (F) Tasmania, Australia. For each region, the top diagram (in chronological order) represents the earliest known community assemblage (determined by archeological evidence for the Aleutian Islands, California and Maine); this is followed by documented phase shifts and associated drivers leading to the present community state. See 'Barrens in regions with documented multiple phase shifts' for detailed explanation of drivers and dynamics for each region. Green balls represent kelp states, pink balls represent barren states and light green or light pink balls indicate a transitional stage (e.g. kelp bed with active urchin grazing patches or barrens with kelp regrowth). Balls with dashed lines represent patchy kelp or barrens; balls with solid lines represent extensive kelp or barrens. Red vertical arrows represent changes in domains of attraction (resilience); dashed black arrows represent shifts from one domain of attraction to another. ${ }^{a}$ A statistical association, not a mechanistic driver

fish, such as cod, haddock and wolffish, which controlled sea urchin Strongylocentrotus droebachiensis populations and maintained the kelp-bed state (Steneck 1997). In the mid-1960s, the functional loss of predatory fish due to fishing enabled sea urchin populations to increase, driving the transition to urchin barrens (Lamb \& Zimmerman 1964, Steneck et al. 2004). The barrens state persisted until 1987, when an urchin fishery opened and decreased densities to the point at which kelp beds could re-establish (McNaught 1999). Currently the kelp-bed state is maintained by crab predation, which limits sea urchin 
recruitment and keeps urchin populations at low densities (Steneck et al. 2004, 2013).

In Eastern Canada, a shift from kelp beds (Laminaria digitata and Saccharina latissima) to barrens was first recorded in the late 1960s to the early 1970s, when dense aggregations of sea urchins overgrazed kelp in a large embayment near Halifax, Nova Scotia (Breen \& Mann 1976, Wharton \& Mann 1981) (Fig. 5D). By the late 1970s, barrens dominated the entire Atlantic coast of Nova Scotia, until recurrent outbreaks of amoebic disease in 1980-1983 caused mass mortalities of sea urchins that enabled kelp beds to reestablish (Scheibling 1984, 1986, Jones 1985, Miller 1985). Initial increases in sea urchin density within kelp beds were attributed to declines of predatory fishes, crabs and lobsters (Wharton \& Mann 1981, Bernstein \& Mann 1982) or possible recruitment events (Hart \& Scheibling 1988). The kelp beds transitioned to barrens again in the early 1990s after sea urchin density increased along the deep margins of kelp beds and recovered in the late 1990s following a widespread recurrence of disease in 1995 and 1999 (Scheibling et al. 1999, Brady \& Scheibling 2005, Kelly et al. 2011). Disease outbreaks in Nova Scotia have been linked to storm activity and warm water temperatures and are becoming increasingly more frequent (Scheibling \& Lauzon-Guay 2010, Scheibling et al. in press). Consequently, kelp beds currently dominate much of the Nova Scotian coast, although barrens exist locally along headlands off central Nova Scotia and the southwestern shore (Feehan et al. 2013).

In the Northeast Atlantic, luxuriant beds of Laminaria hyperborea historically dominated the western coast of Norway (Skadsheim et al. 1995). In 1975, record high densities of the sea urchin Strongylocentrotus droebachiensis destructively grazed kelp beds (Skadsheim et al. 1995) (Fig. 5E) and extensive urchin barrens were created, although sea urchins were unable to remove mature kelp beds under low temperature and high light conditions (Leinaas \& Christie 1996). Sea urchin die-offs in the early 1990s, due to either a macroparasitic infection (Sivertsen 1996) or an unidentified waterborne pathogen (Skadsheim et al. 1995), returned parts of the coast to the kelp-bed state. Currently, northern Norway is dominated by decades-old sea urchin barrens, although kelp beds are re-establishing in southern and central Norway, most likely as a result of low sea urchin recruitment associated with warmer ocean temperatures and increased larval mortality (Sivertsen 2006, Fagerli et al. 2013).

In the Southwest Pacific, a long-term change in the East Australian Current introduced the sea urchin
Centrostephanus rodgersii to coastal Tasmania in the late 1970s (Edgar et al. 2004). This influx of sea urchins caused areas with particularly high sea urchin densities along the northeastern coast of Tasmania to shift from a kelp-dominated (Ecklonia radiata and Phyllospora comosa) state to barrens (Johnson et al. 2005, Ling 2008, Johnson et al. 2011) (Fig. 5F). The resilience of kelp beds to these shifts has likely been reduced by the spiny lobster fishery, which removes an urchin predator from the system (Ling et al. 2009, Ling \& Johnson 2012).

\section{Barrens in regions with one or no documented phase shift}

Isolated phase shifts between kelp forest and barrens states do not offer direct evidence for alternative stable states but can provide information about drivers of transitions and the potential stability of sea urchin barrens. Likewise, long-term reports of sea urchin barrens that occur within the range of kelp distribution, but without documented phase shifts, can provide information about the global prevalence and stability of the barrens state.

In the Northeast Pacific, along the coast of British Columbia, Canada, phase shifts from sea urchin (Strongylocentrotus franciscanus) barrens to kelp forests (Nereocystic luetkeana) were documented following the reintroduction of sea otters in the late 1960s (Breen et al. 1982) and their subsequent range expansion in the 1980s and 1990s (Watson \& Estes 2011). Coastal surveys from 1987 to 2009 showed that kelp forests occurred in areas with continuously high abundances of sea otters, whereas urchin barrens were found in areas where otters were absent (Watson \& Estes 2011). According to local fishermen, parts of the coast were urchin barrens for decades prior to sea otter re-introduction (Breen et al. 1982). A localized phase shift from kelp forests to urchin barrens also was documented off British Columbia, Canada, when destructive grazing by sea urchins $S$. droebachiensis removed a kelp forest in 1973 (Foreman 1977)

In the Northwest Pacific, a similar transition from barrens to a kelp state occurred when sea otters recolonized the Commander Islands in Russia, reducing sea urchin Strongylocentrotus polyacanthus densities and enabling the reestablishment of kelp beds (Saccharina dentigera) (Oshurkov et al. 1988). On the east coast of Japan, sea urchins Strongylocentrotus nudus caused a phase shift from kelp forest (Undaria pinnatifida and Laminaria japonica) to barrens in 
Ogatsu Bay in the 1990s, and prevented kelp regrowth for over $11 \mathrm{yr}$ (Tamaki et al. 2005, 2009). Along the west coast of Hokkaido, Japan, sea urchins were documented overgrazing the kelp forest in the 1930s and formed extensive coralline barrens by the 1960s (Matsunaga et al. 1999, Fujita 2010, Graham 2010). These barrens are most common in areas with low water movement and have been reduced in some areas by harvesting and remediation (sea urchin removal) efforts (Fujita 2010).

In the Southeast Pacific, stable sea urchin (Tetrapygus niger) barrens, interspersed with patches of kelp (Macrocystis integrifolia and Lessonia trabeculata), extend along much of the $2000 \mathrm{~km}$ of coastline of northern Chile (Vásquez \& Buschmann 1997). The resilience of these barrens has likely been increased by unregulated macroalgal harvesting that targets kelp (Vásquez 2008). In southern Chile, only a few localized barrens, maintained by sea urchin Loxechinus albus grazing, have been reported within large tracts of kelp forest (Dayton 1985). Throughout most of this region, sea urchins passively consume drift kelp and do not actively graze kelp stands (Vásquez et al. 1984).

In the Northwest Atlantic, extensive Strongylocentrotus droebachiensis barrens exist along the western, eastern and southern coasts of Newfoundland and southern coast of Labrador, Canada (Keats 1991). Observations of barrens in these regions span periods of $40 \mathrm{yr}$, among the longest on record. Although phase shifts to kelp have not been documented in these areas (Keats 1991), kelp beds (Saccharina latissima) occur in some protected bays adjacent to barrens (Hooper 1975, Keats et al. 1991). Sea urchin removal experiments in Newfoundland showed that macroalgae colonized barrens, but low-lying beds of the brown alga Desmarestia aculeata often dominated the assemblage instead of kelp (Keats et al. 1990). In contrast, the majority of the Greenland coast appears to be largely kelp-dominated (Saccharina spp.), with dense patches of $S$. droebachiensis observed in some regions (Krause-Jensen et al. 2012). Blicher (2010) described a sea urchin barrens spanning $200 \mathrm{~m}$ along the east coast of Greenland, within a protected fjord in the Godthåbsfjord system.

In the Northeast Atlantic, Hjorleifsson et al. (1995) documented sea urchin fronts that emerged from deeper water to graze a kelp bed (Laminaria hyperborea) and form barrens in Iceland. Along the northern coasts of Norway and western Russia, approximately $2000 \mathrm{~km}$ of kelp beds (L. hyperborea) were destructively grazed in the early 1970s, and sea urchin (Strongylocentrotus droebachiensis) barrens have persisted for almost 40 yr (Propp 1977, Sivertsen 1997,
Norderhaug \& Christie 2009). Long-term monitoring of a localized sea urchin (Paracentrotus lividus) barrens in Lough Hyne, Ireland, captured a transition to large brown algae (Cystoseira foeniculacea and Sargassum muticum) in the 1990s that persisted for at least 10 yr (Kitching 1987, Trowbridge et al. 2011). Declines in sea urchin populations within the lough may have been due to disease or predation (Trowbridge et al. 2011).

In the Mediterranean, along the Albères coast in Southern France, $20 \mathrm{~km}$ of macroalgal beds (Cystoseira spp.) collapsed to barrens in the 1970s and have not recovered (Thibaut et al. 2005). The possible causes included overfishing of sea urchin Paracentrotus lividus predators and the recent prohibition on sea urchin collection (Thibaut et al. 2005). In the Adriatic Sea, transitions from macroalgal beds (Cystoseira amentacea) to stable (9 yr) sea urchin (P. lividus) barrens have occurred along $200 \mathrm{~km}$ of coastline (Fanelli et al. 1994, Guidetti et al. 2002, Guidetti et al. 2003). These shifts are attributed to the destructive date mussel fishery, which breaks apart reefs, increasing the availability free space and small spatial refugia. This enhances settlement and recruitment rates of sea urchins, resulting in higher urchin densities on impacted reefs (Guidetti et al. 2003). Management of the fishery enabled macroalgae to recolonize some areas, but urchin barrens persist along most of the coast. Paracentrotus lividus barrens also have been described amid macroalgaldominated (Cystoseira spp.) reefs in the Aegean Sea off the coast of Greece (Giakoumi et al. 2012).

In the Southwest Pacific, urchin barrens have been documented in Eastern Australia and New Zealand. In New South Wales, Australia, about $50 \%$ of $2000 \mathrm{~km}$ of rocky coastline exists in a stable sea urchin (Centrostephanus rodgersii) barrens state (Andrew and Underwood 1989, Andrew \& Underwood 1993, Andrew \& Byrne 2007, Connell \& Irving 2008, Gladstone \& Masens 2009). Small-scale experimental removals of sea urchins from these barrens caused a shift to macroalgal-dominated habitats (Ecklonia radiata) (Fletcher 1987). Along the coasts of New Zealand, urchin barrens have been documented throughout kelp forests (E. radiata) (Shears \& Babcock 2007). In northern New Zealand, the benthos at 6-8 $\mathrm{m}$ depth is dominated by sea urchins Evechinus chloroticus on coralline algal crusts and has persisted for at least $10 \mathrm{yr}$ (Schiel 1990). Establishment of a marine reserve in this region resulted in phase shifts from urchin barrens to kelp forests that were attributed to an increase in fish and invertebrate predators of sea urchins (Leleu et al. 2012). 
Notwithstanding the numerous examples of urchin barrens worldwide, the extent of phase shifts to barrens has in some cases been overstated or exaggerated in the literature. Past reviews have described entire coastlines that alternate between kelp beds and sea urchin barrens, or coastal regions that have remained in a kelp-bed state for thousands of years prior to overfishing (e.g. Steneck et al. 2002). What the evidence actually shows is that $10 \mathrm{~s}$ to $100 \mathrm{~s}$ of $\mathrm{km}$ of temperate coastline in regions around the world, at depth ranges between wave-swept shallows and light-limited deeper waters, can transition between a stable barrens state and a kelp- or macroalgaldominated state (Table 2). The only data on kelp systems older than 200 yr come from a handful of midden sites in Alaska, California and Maine (Erlandson et al. 1996, 2008, Bourque et al. 2008). Although these findings contribute greatly to our understanding of the dynamics of kelp ecosystems (Steneck et al. 2002), they cannot be used to make broad conclusions about the historical state of kelp or barrens ecosystems throughout the world. Furthermore, much of the research on kelp beds and sea urchin barrens comes from well-studied areas, where attention was initially directed to high urchin densities or dramatic ecosystem shifts. As researchers continue to return to regions where barrens have previously been documented, we may be left with a lopsided view of the scale and importance of transitions. Fig. 4 shows large spans of coastal kelp regions where sea urchin barrens have not been documented, mainly due to the lack of research. This indicates the need for a broader perspective to accurately assess the worldwide extent of sea urchin barrens.

\section{THRESHOLDS FOR PHASE SHIFTS AND STATE STABILITY}

Field observations or sea urchin removal and transplantation experiments in Alaska, California, Chile, Nova Scotia, Norway and Tasmania provide estimates of thresholds of urchin density or biomass for phase shifts. These studies consistently show that the threshold required to initiate destructive grazing is much greater than that which enables kelp recovery (Table 3). This difference between thresholds for forward and reverse shifts indicates hysteresis in these dynamics and provides strong evidence of discontinuous phase shifts between alternative stable states. The percentage decrease in the threshold biomass of sea urchins between forward and reverse shifts ranged from 77 to $91 \%$ in these regions. Threshold densities varied markedly among regions, reflecting differences in body size of the dominant sea urchin species, while biomass thresholds were relatively consistent, with order of magnitude differences between forward shifts to barrens (1-3 $\mathrm{kg} \mathrm{m}^{-2}$ ) and reverse shifts to kelp beds $\left(0.1-0.6 \mathrm{~kg} \mathrm{~m}^{-2}\right)$. Thresholds for phase shifts can vary locally with changes in

Table 3. Threshold sea urchin density and biomass required to trigger forward shifts from kelp to barrens states (K $\rightarrow \mathrm{B}$ ) and reverse shifts from barrens to kelp states $(\mathrm{B} \rightarrow \mathrm{K})$ in Alaska, California, Chile, Nova Scotia, Norway and Tasmania. Thresholds were measured using field observations (Obs) during phase shifts or experimental transplantation or removal of sea urchins (Exp). Biomass decrease indicates the percentage decrease in threshold biomass between forward and reverse shifts. Measures were obtained from specific study sites and may not reflect thresholds for entire regions

\begin{tabular}{|c|c|c|c|c|c|c|c|c|c|}
\hline \multirow[t]{2}{*}{ Region } & \multirow[t]{2}{*}{ Method } & \multicolumn{2}{|c|}{$\begin{array}{l}\text { Threshold density } \\
\quad \text { (ind. } \mathrm{m}^{-2} \text { ) }\end{array}$} & \multicolumn{2}{|c|}{$\begin{array}{l}\text { Threshold biomass } \\
\qquad\left(\mathrm{kg} \mathrm{m}^{-2}\right)\end{array}$} & \multirow{2}{*}{$\begin{array}{l}\text { Biomass } \\
\text { decrease } \\
(\%)\end{array}$} & \multirow{2}{*}{$\begin{array}{l}\text { Mean } \\
\text { urchin } \\
\text { mass (g) }\end{array}$} & \multirow{2}{*}{$\begin{array}{c}\text { Kelp } \\
\text { biomass } \\
\left(\mathrm{kg} \mathrm{m}^{-2}\right)\end{array}$} & \multirow[t]{2}{*}{ Source } \\
\hline & & $\mathrm{K} \rightarrow \mathrm{B}$ & $\mathrm{B} \rightarrow \mathrm{K}$ & $\mathrm{K} \rightarrow \mathrm{B}$ & $\mathrm{B} \rightarrow \mathrm{K}$ & & & & \\
\hline Alaska, USA & Exp & 72 & 16 & $1.81^{\mathrm{a}}$ & $0.41^{\mathrm{a}}$ & 77 & 25 & - & Konar \& Estes (2003) \\
\hline California, USA & A Obs & 14 & $2-3$ & $2.81^{\mathrm{a}}$ & $0.4-0.61^{\mathrm{a}}$ & $82^{\mathrm{b}}$ & 200 & $0.2-0.6$ & Dean et al. (1984), Dayton et al. (1992) \\
\hline Chile & Obs & 36 & $20-28$ & - & - & - & - & - & Vásquez et al. (2006) \\
\hline $\begin{array}{l}\text { Nova Scotia, } \\
\text { Canada }\end{array}$ & Obs, Exp & $31-65$ & - & $1.5-3.2^{\mathrm{c}}$ & $0.15-0.25$ & $91^{\mathrm{b}}$ & 49 & $2.0-5.0$ & $\begin{array}{l}\text { Breen \& Mann (1976), Chapman (1981) } \\
\text { Lauzon-Guay \& Scheibling (2007a), } \\
\text { Scheibling et al. (1999) }\end{array}$ \\
\hline Norway & Obs, Exp & $45-75$ & 10 & $1.0-1.7^{\mathrm{a}}$ & $0.22^{\mathrm{a}}$ & $84^{\mathrm{b}}$ & 22 & 1.0 & $\begin{array}{l}\text { Hagen (1995), Leinaas \& Christie } \\
\text { (1996), Sjøtun et al. (1998) }\end{array}$ \\
\hline $\begin{array}{l}\text { Tasmania, } \\
\text { Australia }\end{array}$ & Obs, Exp & $4-10$ & $0.2-1.2$ & $0.9-2.3^{\mathrm{d}}$ & $0.05-0.28^{\mathrm{d}}$ & $90^{\mathrm{b}}$ & 230 & 0.8 & $\begin{array}{l}\text { Ling (2008), Ling et al. (2009), Pecorino } \\
\text { et al. (2012), Marzloff et al. (2013) }\end{array}$ \\
\hline
\end{tabular}


hydrodynamic conditions. Strong wave action can inhibit aggregative feeding behaviour of sea urchins by limiting their ability to climb kelp stipes and anchor blades (Lauzon-Guay \& Scheibling 2007a). Experimental transplantation of sea urchins in kelp beds in Alaska and Nova Scotia showed that the density threshold for destructive grazing was lower within kelp beds than along the kelp-barrens interface at the edge of beds, where wave action is greater (Konar \& Estes 2003, Feehan et al. 2012). The biomass of kelp also can directly influence the threshold urchin biomass for destructive grazing and a shift to barrens (Lauzon-Guay \& Scheibling 2007b, Lauzon-Guay et al. 2009).

Once threshold urchin densities are attained, phase shifts between kelp beds and barrens are relatively abrupt. Destructive grazing creates positive feedback mechanisms that accelerate the shift to barrens. Actively grazing sea urchins have unlimited, high quality food, which enables them to grow rapidly and allocate a large amount of energy to reproduction (Meidel \& Scheibling 1998). Because highly fecund sea urchins are aggregating in high densities, fertilization rates are maximal (Meidel \& Scheibling 2001, Lauzon-Guay \& Scheibling 2007c), which likely increases larval supply and recruitment to barrens on regional scales. Similarly, when sea urchin densities in barrens drop significantly, the release from grazing triggers an immediate response: filamentous algae and diatoms appear within days of urchin removal, and kelps recruit and grow into canopies within 1 to $3 \mathrm{yr}$ (Duggins 1980, Harrold \& Reed 1985, Johnson \& Mann 1988, Tegner et al. 1997, McNaught 1999, Konar \& Estes 2003, Ling 2008, Ford \& Meux 2010, Watanuki et al. 2010, Watson \& Estes 2011).

There are 2 types of feedback mechanisms that stabilize the community assemblage in the barrens state: processes that reduce kelp recruitment on barrens and processes that allow sea urchins to maintain high densities on barrens (Fig. 6). Sea urchins in barrens prevent kelp recruitment by continually scraping coralline algal crusts, consuming the surficial layers along with any microalgal films and macroalgal recruits (Chapman 1981). This reduces the survival of kelp sporophytes in barrens (Jones \& Kain 1967). Sea urchin exclusion experiments in the Gulf of St. Lawrence,
Canada, found that kelp recruitment was 100 times higher on barrens without urchins than on barrens with urchins (Gagnon et al. 2004). In widespread barrens, the urchin-dominated state may be further stabilized by a lack of reproductive source populations of kelp that provide spores for recruitment (Keats 1991). Kelp spores are short-lived and typically settle within 5 to $10 \mathrm{~m}$ of the parent plant (Norton 1992, Gaylord et al. 2012), although maximum dispersal distances of up to $5 \mathrm{~km}$ have been measured for some species (e.g. Laminaria hyperborea, Norton 1992; Macrocystis pyrifera, Gaylord et al. 2006). In Nova Scotia, barrens adjacent to shallow stands of reproductive kelp sporophytes re-established kelp beds within 18 mo following urchin mass mortality, whereas it took $4 \mathrm{yr}$ for kelp beds to recover on barrens that were $3 \mathrm{~km}$ away from the nearest reproductive kelps (Johnson \& Mann 1988). Likewise, sea urchin removal experiments conducted within extensive barrens off Newfoundland, Canada, did not result in colonization by kelp after $3 \mathrm{yr}$, because the nearest reproductive kelps were several kilometers away from the removal plots (Keats 1991, Keats et al. 1990). This effect may be mitigated in barrens where a few remaining sporophytes are exposed to elevated light, nutrients and currents, which can result in greater fecundity. In the Aleutian Islands, individual sporophytes of Eualaria fistulosa in barrens produced 3 times more spores than individual sporophytes in adjacent kelp

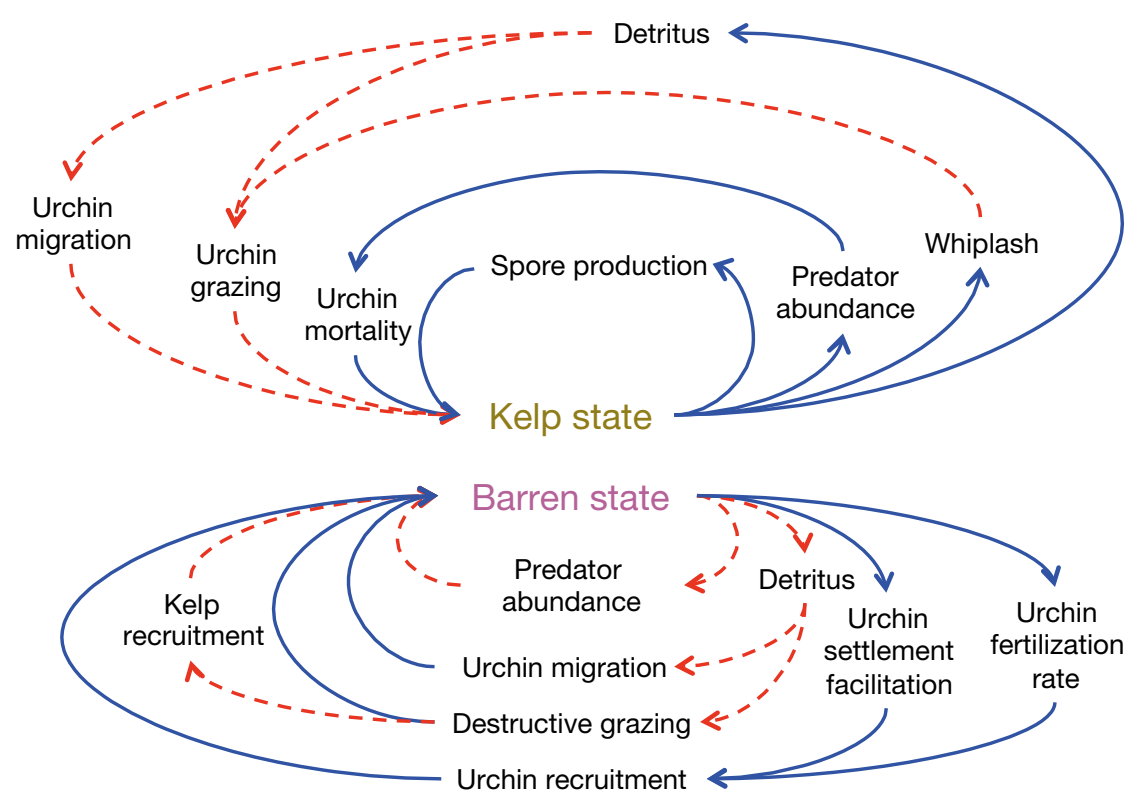

Fig. 6. Stabilizing feedback mechanisms for the kelp-bed and sea urchin barrens states. Blue (solid line) is positive and red (dashed line) is negative feedback; 2 sequential negative feedbacks indicate an indirect positive feedback 
forests (Edwards \& Konar 2012). In California, some kelp species form free-floating rafts that can disperse spores over great distances and may mitigate the loss of reproductive sporophytes in widespread barrens (Hobday 2000).

Despite the lack of kelp and other fleshy macroalgae as food sources, sea urchins can maintain high densities on barrens by allocating fewer resources to reproduction and growth, undergoing morphological changes in their body wall (Edwards \& Ebert 1991), and reabsorbing parts of their body wall or gut (Pearse et al. 1970). High densities of sea urchins in barrens can offset decreased individual reproductive output, enabling populations to sustain moderately high fertilization rates and contribute to the larval pool (Lauzon-Guay \& Scheibling 2007c). However, since sea urchins have a planktonic larval stage of 2-3 mo and can disperse distances of up to 100 to $1000 \mathrm{~km}$ (Huggett et al. 2005), any positive impact of a larger larval pool on sea urchin settlement would likely be limited to large-scale barrens (100s of $\mathrm{km})$.

Settlement of sea urchins in barrens is enhanced by a chemical cue associated with coralline algae that induces settlement and metamorphosis of sea urchin larvae (Pearse \& Scheibling 1990). Therefore, by preventing kelps and other fleshy or filamentous macroalgae from overgrowing and outcompeting corallines, sea urchin grazing in barrens facilitates the supply of new individuals to the population (Miner et al. 2006, Hernández et al. 2010). Baskett \& Salomon (2010) generated discontinuous phase shifts between barrens and kelp beds in a model that incorporated sea urchin grazing on kelp, competition between kelp and coralline algae, and facilitation of sea urchin recruitment by coralline algae. Sea urchins in barrens likely experience lower postsettlement mortality due to predation compared with kelp beds, which also acts to increase recruitment and stabilize a barrens state. The low structural complexity of barrens, compared with the 3-dimensional structure of kelp beds, limits available habitat for predators of sea urchins, such as decapod crustaceans and fish (Levin 1994, Konar \& Estes 2003, Gianguzza et al. 2010), including those that prey on the early juvenile stages (Hacker \& Steneck 1990, Bonaviri et al. 2012).

The decrease in kelp cover during a shift to the barrens state reduces the supply of kelp detritus both to shallow kelp beds (Ebeling et al. 1985) and to adjacent habitats in deeper regions (Vanderklift \& Kendrick 2005, Krumhansl \& Scheibling 2011). Resident sea urchins in kelp beds, like those in deeper regions, generally feed passively on drift kelp (Harrold \& Reed 1985, Filbee-Dexter \& Scheibling 2012). When this subsidy declines, urchins emerge from shelters to actively graze attached kelp and augment populations in barrens, providing another form of feedback that can stabilize the kelp-bed state.

A healthy kelp bed is maintained by various feedback mechanisms that prevent the increases in sea urchin density that lead to destructive grazing and the formation of barrens (Fig. 6). Algal films and understory algae inhibit settlement of sea urchin larvae by reducing the availability of open space on rocky substrata (Trowbridge et al. 2011). High levels of predation on juvenile urchins in kelp habitats compared with barrens limits recruitment (Tegner \& Dayton 1981, Leinaas \& Christie 1996, Scheibling 1996). Sea urchins within kelp beds often are cryptic, sheltering in spatial refuges from predators (e.g. crevices, undersides of boulders, and kelp hodlfasts); few reach a size refuge from all but the largest predators (Scheibling \& Hamm 1991, Clemente et al. 2007).

The physical structure of kelp beds also can prevent sea urchin grazing. The wave-driven whiplash and sweeping motion of large kelps impedes urchins from moving into kelp beds (Vásquez 1992, Konar 2000, Tamaki et al. 2009). In experimental kelp removals in Alaska, Konar \& Estes (2003) showed that sea urchins advanced beyond the deep margins of kelp forests (at 8-13 m depth) when kelp was removed but not when kelp was replaced with physical mimics, indicating that the sweeping motion of kelp arrested the onshore advance of grazing aggregations. Dislodgment of sea urchins may also be higher in kelp beds compared with barrens. In a laboratory study using a flume, Kawamata (2010) showed that sea urchins attached to turf algae stopped actively moving and were dislodged at lower water velocities than when attached to bare rock.

The high production of detrital material within kelp beds (Krumhansl \& Scheibling 2012) provides an important subsidy for resident sea urchins (Harrold \& Reed 1985) and offshore populations (Britton-Simmons et al. 2009, Filbee-Dexter \& Scheibling 2012). This reliance on passive detrivory lowers grazing intensity on attached kelp (Day \& Branch 2000) and likely reduces adult migration into kelp beds. In contrast, detrital subsidy from a highly productive kelp state can also enhance reproductive output of offshore sea urchin populations (Britton-Simmons et al. 2009, K. Filbee-Dexter, unpubl. data), which could increase the larval pool and, consequently, settlement of sea urchins in the kelp bed. 


\section{ARE SEA URCHIN BARRENS AN ALTERNATIVE STABLE STATE?}

With some exceptions, sea urchin barrens generally result from discontinuous phase shifts and therefore are considered an alternative stable state of kelp ecosystems (Table 2). Phase shifts between kelp beds and sea urchin barrens show evidence of hysteresis after a transition (Table 3), and both the kelp and barrens states are stabilized by numerous feedback mechanisms and are resistant to small perturbations or fluctuations in sea urchin densities. Sea urchin barrens can persist for decades and exist under environmental conditions similar to those of kelp beds. Most shifts to barrens are driven by localized changes in state variables and parameters and as such are not a part of a larger oceanic regime shift linked to climate change or climate oscillations. Exceptions are the phase shifts observed in Tasmania and California that are caused by changing ocean currents. The rapidly changing ocean temperature in Tasmania due to the increased southern penetration of the East Australian Current may constitute an oceanic regime shift (Johnson et al. 2011). Likewise, periodic changes in coastal upwelling in California due to the El Niño-Southern Oscillation also may represent an oceanic regime shift (Tegner \& Dayton 1987, Dayton \& Tegner 1990).

We find little evidence supporting prior arguments that human-induced shifts between kelp beds and barrens constitute continuous phase shifts that are maintained by ongoing anthropogenic impacts (Connell \& Sousa 1983, Petraitis \& Dudgeon 2004). In ecosystems where human perturbations cause phase shifts, hysteresis still occurs and the alternative state persists after the human control is relaxed (Tables 2 \& 3). However, human activities such as moratoria on otter hunting, expanding sea urchin fisheries, or continued depletion of groundfish are likely increasing the occurrence of phase shifts in kelp ecosystems (Scheffer et al. 2001, Knowlton 2004). The dramatic changes in sea urchin densities that are required to trigger phase shifts may be difficult to achieve through natural causes but could readily occur through strong anthropogenic perturbations (Knowlton 2004). Given that humans are increasingly impacting ocean ecosystems globally, the implications of human perturbations in triggering phase shifts in kelp ecosystems are of growing concern.

In kelp ecosystems that exhibit alternative state dynamics, the recovered community state often differs from the state that existed prior to a collapse. For example, in Maine, the groundfish associated with kelp beds in the 1930s and subsequently depleted by coastal fisheries were not re-established with the return to the kelp state in the 1990s (Steneck et al. 2004). In California, the sheepshead fish and lobster populations that controlled sea urchins in kelp forests in the 1930s did not recover in kelp forests in the 1970s (Dayton et al. 1998). In the Aleutian Islands, sea otter populations in re-established kelp forests are encountering a new agent of mortality in the form of killer whale predation (Estes et al. 1998, Tegner \& Dayton 2000). In the last 3 decades, climate change has been implicated in lowering recruitment of sea urchins in Norway (Fagerli et al. in 2013), increasing the frequency of disease outbreaks that cause mass mortality of sea urchins in Nova Scotia (Scheibling et al. in press), and modifying currents that have expanded the range of sea urchins into Tasmania (Johnson et al. 2011). The escalating influences of humans in each of these regions may be causing phase shifts to new, more deteriorated ecosystem states with fewer species, less biomass and increased levels of human impact, rather than alternations between 2 persistent community configurations. Although human perturbations may be altering the resilience of these communities, they still exhibit broad domains of attraction in both the kelp-dominated and urchin barrens state, which allows their classification as alternative stable-state systems.

\section{IMPLICATIONS FOR MANAGEMENT OF KELP- BASED ECOSYSTEMS}

Given that phase shifts to barrens often are considered as manifestations of the collapse of a kelp-based ecosystem, various strategies have been attempted to recover the productive kelp state. By definition, system recovery can be challenging after a discontinuous phase shift because of hysteresis, making it difficult to reverse a collapse (Scheffer et al. 2001). Even so, some forms of management, particularly those focused on controlling populations of urchin predators, have been effective in restoring kelp forests. Actions to reestablish populations of the sea otter Enhydra lutris, considered a keystone species in the North Pacific for its cascading effects on kelp abundance (Paine 1969), provide an early example of this strategy. Historical moratoria on sea otter hunting effectively restored populations in eastern Russia, western Alaska and California, and together with sea otter translocations across the eastern Pacific, led to the recovery of kelp forests in many regions (Estes \& Palmisano 1974, Breen et al. 1982). Currently, sea otter populations are 
declining because of oil spills (Bodkin et al. 2002), disease (Kannan et al. 2006) and killer whale predation (Doroff et al. 2003). Wilmers et al. (2012) proposed that proper otter conservation strategies would maximize kelp forest abundance in the northeast Pacific and create an important carbon sink.

The establishment of marine reserves also can restore predator populations and recover the kelp state. In New Zealand, increased lobster and predatory fish populations, and substantial re-growth of kelp, was documented in marine protected areas compared with unregulated areas (Babcock et al. 1999, Shears \& Babcock 2003, Shears et al. 2006, Leleu et al. 2012). In the Adriatic Sea, the percentage cover of barrens was lower in marine reserves where fishing prohibitions are strictly enforced than in unmonitored areas where poaching occurs (Guidetti et al. 2003). In Tasmania, marine reserves increased spiny lobster populations and maintained the kelp state by limiting the potential for destructive grazing by sea urchins through higher predation rates (Ling \& Johnson 2012). However, the effectiveness of such protection strategies can be limited. In Tasmania, a large-scale experimental introduction of thousands of spiny lobsters into both widespread barrens and patchy barrens amid kelp beds resulted in no increase in kelp cover in widespread barrens and only a small increase in kelp cover in patchy barrens (S. D. Ling pers. comm.). This indicates that the barrens state is extremely resilient to kelp recovery (Marzloff et al. 2013), and only preventative management to increase the resilience of the kelp-bed state may be effective in halting phase shifts to barrens.

Judicious management of fisheries may recover kelp assemblages. Sea urchin fisheries in Maine and California have reduced sea urchin densities below thresholds that maintain barrens, enabling a reverse shift to a kelp-dominated state (Tegner \& Dayton 1991, Steneck et al. 2004). In Nova Scotia, the sea urchin fishery manages the stock by targeting the grazing front at the deep edge of a kelp bed (Miller \& Nolan 2000). This halts or slows the advance of fronts until trailing sea urchins in the barrens encounter the kelp and re-establish aggregations, allowing for a sustainable harvest (Miller \& Nolan 2000). In California, commercial kelp harvesters prevented sea urchin grazing fronts from advancing into kelp forests using quicklime, before the establishment of an urchin fishery (North 1971). In Japan, artificial reefs have been suspended above the substratum on buoyed arrays to exclude sea urchins, resulting in the recovery of kelps for commercial harvest (Tamaki et al. 2009).
An unexplored strategy for conserving the kelp state could involve managing human impacts that affect feedback mechanisms in kelp systems. For example, minimizing kelp harvesting or coastal sedimentation due to runoff would increase kelp biomass. This would increase the supply of drift kelp, which could prevent behavioural switches to active grazing in resident sea urchins. Similarly, seeding barren areas with reproductive kelp fronds could enhance kelp settlement in regions with limited spores. A better understanding of the feedback mechanisms that stabilize the barrens state may help inform management strategies.

Two major challenges face effective management of kelp-bed and barrens ecosystems. First, management strategies require a clear understanding of individual ecosystems, as the relative importance of stabilizing mechanisms and drivers of state shifts can vary with species composition, trophic interactions, functional redundancy and environmental conditions that are unique to each system. Successful management of barrens has mainly been limited to wellstudied systems where the drivers of transitions are well understood. Further research is needed in other regions of the kelp range, such as South America, Africa, Asia and the Arctic. Second, it is not possible to manage phase shifts resulting from environmental changes, such as warming oceans, increased storm severity, and altered currents (Ebeling et al. 1985, Ling 2008, Harley et al. 2012, Scheibling et al. in press). These changes may be mitigated to some extent by maintaining high biodiversity and species richness within kelp beds (Folke et al. 2004), as phase shifts to barrens tend to be more common in systems with low trophic complexity and low functional redundancy (Steneck et al. 2002). However, future impacts of climate change on these ecosystems greatly exceed the management capacities of coastal areas and would require a larger global initiative that prevents further environmental change in ocean ecosystems.

\section{PERSPECTIVES FOR FUTURE RESEACH}

Kelp forests or beds are complex ecosystems that have the potential to drastically change in terms of both structure and function through phase shifts to sea urchin barrens. To fully understand whether barrens represent an alternative stable state of kelp ecosystems, further longitudinal studies of kelp and barrens communities are required. Manipulative field experiments typically provide the strongest evidence of alternative stable states and can be 
used to elucidate thresholds for state shifts as well as system-specific feedback mechanisms that can stabilize both kelp and barrens states. For example, sea urchin removal experiments not only indicate the potential macroalgal community that can develop within barren grounds but also can be used to quantify thresholds for recovery of the kelp state. Long-term monitoring programs and statistical models are also useful in evaluating the stability and organization of different ecosystem states (Johnson et al. 2013, Marzloff et al. 2013). A major source of uncertainty in kelp and barrens ecosystems is the period between sea urchin larval release and settlement. In the majority of these ecosystems, the fate of larvae produced by resident populations in barrens, kelp beds or nearby deep areas is largely unexplored and likely plays an important role in both driving density-induced phase shifts and stabilizing the barrens or kelp state.

There are several trends in the global occurrence of sea urchin barrens that may warrant further research. It is unclear why barrens dominate throughout eastern Canada, western Russia and northern Norway but are rarely documented along the coasts of Greenland and Iceland, regions with similar species composition and environmental conditions. Sea urchin barrens also tend to be more widespread and phase shifts occur more frequently along temperate coasts in the northern hemisphere than along tropical and south temperate coasts. The trend of increasing marine species richness and ecosystem complexity from the Arctic to the tropics (Gray 2001) may explain this discrepancy because the more simplified food webs in temperate ecosystems may collapse more readily. Southern kelp beds also occur in upwelling zones, which may have altered feedbacks and dynamics compared with temperate ecosystems.

Considerable attention has been directed towards establishing criteria for defining an alternative stable state (Connell \& Sousa 1983, Beisner et al. 2003, Petraitis \& Dudgeon 2004). However, in a practical sense, regardless of whether phase shifts between kelp beds and barrens reflect an actual alternative stable-state system, the barrens state typically exhibits multiple feedback mechanisms that can inhibit kelp recovery for decades. As Knowlton (2004) aptly observed, in the context of marine conservation, it probably makes little difference in human time scales if sea urchin barrens persist indefinitely; what matters is that the system can undergo a long-term departure from prevailing conditions that is difficult to reverse.
Acknowledgements. We thank A. Metaxas, S. Ling, C. Feehan, K. Krumhansl, S. Walde and H. Whitehead for helpful comments on earlier drafts of the manuscript. This research was funded by a Discovery Grant to R.E.S. from the Natural Sciences and Engineering Research Council (NSERC) of Canada. K.F.-D. was supported by a Dalhousie Killam Scholarship and an NSERC Canada Graduate Scholarship.

\section{LITERATURE CITED}

Alves F, Chícharo LM, Serrao E, Abreu AD (2001) Algal cover and sea urchin spatial distribution at Madeira Island (NE Atlantic). Sci Mar 65:383-392

Andrew N, Byrne M (2007) Ecology of Centrostephanus. In: Lawrence JM (ed) Edible sea urchins: biology and ecology. Elsevier, Amsterdam, p 191-204

Andrew NL, Underwood AJ (1989) Patterns of abundance of the sea urchin Centrostephanus rodgersii (Agassiz) on the central coast of New South Wales, Australia. J Exp Mar Biol Ecol 131:61-80

Andrew NL, Underwood AJ (1993) Density-dependant foraging in the sea urchin Centrostephanus rodgersii on shallow subtidal reefs in New South Wales, Australia. Mar Ecol Prog Ser 99:89-98

Babcock RC, Kelly S, Shears NT, Walker JW, Willis TJ (1999) Changes in community structure in temperate marine reserves. Mar Ecol Prog Ser 189:125-134

Baskett ML, Salomon AK (2010) Recruitment facilitation can drive alternative states on temperate reefs. Ecology 91:1763-1773

Beisner BE, Haydon DT, Cuddington K (2003) Alternative stable states in ecology. Front Ecol Environ 1:376-382

Bernstein BB, Mann KH (1982) Changes in the nearshore ecosystem of the Atlantic coast of Nova Scotia, 1968-81. NAFO Sci Counc Stud 5:101-105

> Bischoff B, Wiencke C (1993) Temperature requirements for growth and survival of macroalgae from Disko Island (Greenland). Helgol Meeresunters 47:167-191

Blicher ME (2010) Structure and dynamics of marine macrozoobenthos in Greenland and the link to environmental drivers. PhD dissertation, Greenland Climate Research Centre \& Department of Biology, Greenland Institute of Natural Resources, University of Copenhagen

$>$ Bodkin JL (1988) Effects of kelp forest removal on associated fish assemblages in central California. J Exp Mar Biol Ecol 117:227-238

> Bodkin JL, Ballachey BE, Dean TA, Fukuyama AK and others (2002) Sea otter population status and the process of recovery from the 1989 'Exxon Valdez' oil spill. Mar Ecol Prog Ser 241:237-253

> Bonaviri C, Gianguzza P, Pipitone C, Hereu B (2012) Micropredation on sea urchins as a potential stabilizing process for rocky reefs. J Sea Res 73:18-23

Bourque BJ, Johnson BJ, Steneck RS (2008) Possible prehistoric fishing effects on coastal marine food webs in the Gulf of Maine. In: Erlandson J, Rick T (eds) Human impacts on ancient marine ecosystems: a global perspective. University of California Press, Berkeley, CA, p 165-185

> Brady SM, Scheibling RE (2005) Repopulation of the shallow subtidal zone by green sea urchins (Strongylocentrotus droebachiensis) following mass mortality in N. Canada. J Mar Biol 85:1511-1517

> Breen PA, Mann KH (1976) Destructive grazing of kelp by 
sea urchins in eastern Canada. J Fish Res Board Can 33:1278-1283

- Breen PA, Carson TA, Foster JB, Stewart EA (1982) Changes in subtidal community structure associated with British Columbia sea otter transplants. Mar Ecol Prog Ser 7: 13-20

Britton-Simmons KH, Foley G, Okamoto D (2009) Spatial subsidy in the subtidal zone: utilization of drift algae by a deep subtidal sea urchin. Aquat Biol 5:233-243

Casini M, Hjelm J, Molinero JC, Lövgren J and others (2009) Trophic cascades promote threshold-like shifts in pelagic marine ecosystems. Proc Natl Acad Sci USA 106:197-202

- Chapman ARO (1981) Stability of sea urchin dominated barren grounds following destructive grazing of kelp in St. Margarets Bay, eastern Canada. Mar Biol 62:307-311

Chapman ARO, Johnson CR (1990) Disturbance and organization of macroalgal assemblages in the northwest Atlantic. Hydrobiologia 192:77-121

Chapman ARO, Lindley JE (1981) Productivity of Laminaria solidungula in the Canadian high Arctic: a year-round study. In: Levring $\mathrm{T}$ (ed) 10th International Seaweed Symposium Proceedings. Walter de Gruyter, Berlin, p 247-252

Choat JH, Schiel DR (1982) Patterns of distribution and abundance of large brown algae and invertebrate herbivores in subtidal regions of northern New Zealand. J Exp Mar Biol Ecol 60:129-162

> Christie H, Norderhaug KM, Fredriksen S (2009) Macrophytes as habitat for fauna. Mar Ecol Prog Ser 396: 221-233

- Clemente S, José CH, Toledo K, Brito A (2007) Predation upon Diadema antillarum in barren grounds in the Canary Islands. Sci Mar 71:745-754

Collie JS, Richardson K, Steele JH (2004) Regime shifts: Can ecological theory illuminate the mechanisms? Prog Oceanogr 60:281-302

> Connell JH, Sousa WP (1983) On evidence needed to judge ecological stability or persistence. Am Nat 121:789-824

Connell SD, Irving AD (2008) Integrating ecology with biogeography using landscape characteristics: a case study of subtidal habitat across continental Australia. J Biogeogr 35:1608-1621

Cross WE, Wilce RT, Fabijan MF (1987) Effects of experimental releases of oil and dispersed oil on Arctic nearshore macrobenthos. III. Macroalgae. Arctic 40:211-219

> Day EG, Branch GM (2000) Evidence for a positive relationship between juvenile abalone Haliotis midae and the sea urchin Parechinus angulosus in the south-western Cape, South Africa. S Afr J Mar Sci 22:145-156

> Dayton PK (1985) Ecology of kelp communities. Annu Rev Ecol Syst 16:215-245

Dayton PK, Tegner MJ (1990) Bottoms beneath troubled waters: benthic impacts of the 1982-1984 El Niño in the temperate zone. In: Glynn PW (ed) Global consequences of the 1982-1983 El Niño-Southern Oscillation. Elsevier Oceanography Series, Amsterdam, p 433-466

> Dayton PK, Currie V, Gerrodette T, Keller BD, Rosenthal R, Tresca DV (1984) Patch dynamics and stability of some California kelp communities. Ecol Monogr 54:253-289

> Dayton PK, Tegner MJ, Parnell PE, Edwards PB (1992) Temporal and spatial patterns of disturbance and recovery in a kelp forest community. Ecol Monogr 62:421-445

> Dayton PK, Tegner MJ, Edwards PB, Riser KL (1998) Sliding baselines, ghosts, and reduced expectations in kelp forest communities. Ecol Appl 8:309-322
Dayton PK, Tegner MJ, Edwards PB, Riser KL (1999) Temporal and spatial scales of kelp demography: the role of the oceanographic climate. Ecol Monogr 69:219-250

$>$ Dean TA, Schroeter SC, Dixon JD (1984) Effects of grazing by two species of sea urchins (Strongylocentrotus franciscanus and Lytechinus anamesus) on recruitment and survival of two species of kelp (Macrocystis pyrifera and Pterygophora californica). Mar Biol 78:301-313

> DeYoung B, Harris R, Alheit J, Beaugrand G, Mantua N, Shannon L (2004) Detecting regime shifts in the ocean: data considerations. Prog Oceanogr 60:143-164

> Doroff AM, Estes JA, Tinker MT, Burn DM, Evans TJ (2003) Sea otter population declines in the Aleutian archipelago. J Mammal 84:55-64

> Dudgeon SR, Aronson RB, Bruno JF, Precht WF (2010) Phase shifts and stable states on coral reefs. Mar Ecol Prog Ser 413:201-216

> Duggins DO (1980) Kelp beds and sea otters: an experimental approach. Ecology 61:447-453

$>$ Duggins DO, Simenstad CA, Estes JA (1989) Magnification of secondary production by kelp detritus in coastal marine ecosystems. Science 245:170-173

> Dumont C, Himmelman JH, Russell MP (2004) Size-specific movement of green sea urchins Strongylocentrotus droebachiensis on urchin barrens in eastern Canada. Mar Ecol Prog Ser 276:93-101

Dunton KH, Reimnitz E, Schonberg S (1982) An arctic kelp community in the Alaskan Beaufort Sea. Arctic 35: 465-484

> Ebeling AW, Laur DR, Rowley RJ (1985) Severe storm disturbances and reversal of community structure in a southern California kelp forest. Mar Biol 84:287-294

Ebert EE (1968) California sea otter-census and habitat survey. Underwat Nat 5:20-23

Ebert TA, Southon JR (2003) Red sea urchins (Strongylocentrotus franciscanus) can live over 100 years: confirmation with A-bomb ${ }^{14}$ carbon. Fish Bull 101:915-922

> Edgar GJ, Barrett NS, Morton AJ, Samson CR (2004) Effects of algal canopy clearance on plant, fish and macroinvertebrate communities on eastern Tasmanian reefs. J Exp Mar Biol Ecol 312:67-87

> Edwards PB, Ebert TA (1991) Plastic responses to limited food availability and spine damage in the sea urchin Strongylocentrotus purpuratus. J Exp Mar Biol Ecol 145: 205-220

> Edwards MS, Konar B (2012) A comparison of dragon kelp Eualaria fistulosa, (Phaeophyceae) fecundity in urchin barrens and nearby kelp beds throughout the Aleutian archipelago. J Phycol 48:897-901

Erlandson JM, Kennett DJ, Ingram BL, Guthrie DA and others (1996) An archaeological and palaeontological chronology for Daisy Cove (CA-SMI-261), San Miguel Island, California. Radiocarbon 38:355-373

Erlandson JM, Rick TC, Estes JA, Graham MH, Braje TJ, Vellanoweth RL (2008) Sea otters, shellfish, and humans: a 10,000 year record from San Miguel Island, California. J Archaeol Sci 35:2144-2152

- Estes JA, Palmisano JF (1974) Sea otters: their role in structuring nearshore communities. Science 185:1058-1060

> Estes JA, Smith NS, Palmisano JF (1978) Sea otter predation and community organization in the western Aleutian islands, Alaska. Ecology 59:822-833

Estes JA, Tinker MT, Williams TM (1998) Killer whale predation on sea otters linking oceanic and nearshore ecosystems. Science 282:473-476 
Fagerli CW, Norderhaug KM, Christie HC (2013) Lack of sea urchin settlement may explain kelp forest recovery in overgrazed areas in Norway. Mar Ecol Prog Ser 488: 119-132

Fanelli G, Piraino S, Belmonte G, Geraci S, Boero F (1994) Human predation along Apulian rocky coasts (SE Italy): desertification caused by Lithophaga lithophaga (Mollusca) fisheries. Mar Ecol Prog Ser 110:1-8

Feehan C, Scheibling RE, Lauzon-Guay JS (2012) Aggregative feeding behavior in sea urchins leads to destructive grazing in a Nova Scotian kelp bed. Mar Ecol Prog Ser 444:69-83

- Feehan CJ, Johnson-Mackinnon J, Scheibling RE, LauzonGuay JS, Simpson AGB (2013) Validating the identity of Paramoeba invadens, the causative agent of recurrent mass mortality of sea urchins in Nova Scotia, Canada. Dis Aquat Org 103:209-227

- Filbee-Dexter K, Scheibling RE (2012) Hurricane-mediated defoliation of kelp beds and pulsed delivery of kelp detritus to offshore sedimentary habitats. Mar Ecol Prog Ser 455:51-64

> Fletcher WJ (1987) Interactions among subtidal Australian sea urchins, gastropods and algae: effects of experimental removals. Ecol Monogr 57:89-109

Folke C, Carpenter S, Walker B, Scheffer M, Elmqvist T, Gunderson L, Holling CS (2004) Regime shifts, resilience, and biodiversity in ecosystem management. Annu Rev Ecol Syst 35:557-581

Ford T, Meux B (2010) Giant kelp community restoration in Santa Monica Bay. Urban Coast 2:43-46

- Foreman RE (1977) Benthic community modification and recovery following intensive grazing by Strongylocentrotus droebachiensis. Helgol Meeresunters 30:468-484

Fujita D (1998) Strongylocentrotid sea urchin-dominated barren grounds on the Sea of Japan coast of northern Japan. In: Mooi R, Telford M (eds) Echinoderms. Balkema, Rotterdam, p 659-664

Fujita D (2010) Current status and problems of isoyake in Japan. Bull Fish Res Agency 32:33-42

Fung T, Seymour RM, Johnson CR (2011) Alternative stable states and phase shifts in coral reefs under anthropogenic stress. Ecology 92:967-982

> Gagnon P, Himmelman JH, Johnson LE (2004) Temporal variation in community interfaces: kelp-bed boundary dynamics adjacent to persistent urchin barrens. Mar Biol 144:1191-1203

Gaylord B, Reed DC, Raimondi PT, Washborn L (2006) Macroalgae spore dispersal in coastal environments: mechanistic insights revealed by theory and experiment. Ecol Monogr 76:481-502

> Gaylord B, Nickols KJ, Jurgens L (2012) Roles of transport and mixing processes in kelp forest ecology. J Exp Biol 215:997-1007

Giakoumi S, Cebrian E, Kokkoris GD, Ballesteros E, Sala E (2012) Relationships between fish, sea urchins and macroalgae: the structure of shallow rocky sublittoral communities in the Cyclades, Eastern Mediterranean. Estuar Coast Shelf Sci 109:1-10

Gianguzza P, Bonaviri C, Milisenda G, Barcellona A, Agnetta D, Vega Fernández T, Badalamenti F (2010) Macroalgal assemblage type affects predation pressure on sea urchins by altering adhesion strength. Mar Environ Res 70:82-86

Gladstone W, Masens O (2009) Monitoring and assessment of urchin barrens as a marine condition indicator. Hunter-
Central Rivers Catchment Management Authority, University of Newcastle

Glud RN, Woelfel J, Karsten U, Kühl M, Rysgaard S (2009) Benthic microalgal production in the Arctic: applied methods and status of the current database. Bot Mar 52:559-572

> Graham MH (2004) Effects of local deforestation on the diversity and structure of Southern California giant kelp forest food webs. Ecosystems 7:341-357

Graham MH (2010) Comparisions between East-Asian isoyake and deforestation in global kelp ecoystems. Bull Fish Res Agen 32:47-50

Gray JS (2001) Marine diversity: the paradigms in patterns of species richness examined. Sci Mar 65:41-56

- Grimm V, Wissel C (1997) Babel, or the ecological stability discussions: an inventory and analysis of terminology and a guide for avoiding confusion. Oecologia 109: 323-334

Guidetti P, Fanelli G, Fraschetti S, Terlizzi A, Boero F (2002) Coastal fish indicate human-induced changes in the Mediterranean littoral. Mar Environ Res 53:77-94

Guidetti P, Fraschetti S, Terlizzi A, Boero F (2003) Distribution patterns of sea urchins and barrens in shallow Mediterranean rocky reefs impacted by the illegal fishery of the rock-boring mollusc Lithophaga lithophaga. Mar Biol 143:1135-1142

Hacker SD, Steneck RS (1990) Habitat architecture and the abundance and body-size-dependent habitat selection of a phytal amphipod. Ecology 71:2269-2285

> Hagen NT (1995) Recurrent destructive grazing of successionally immature kelp forests by green sea urchins in Vestfjorden, Northern Norway. Mar Ecol Prog Ser 123: 95-106

Harley CD, Anderson KM, Demes KW, Jorve JP, Kordas RL, Coyle TA, Graham MH (2012) Effects of climate change on global seaweed communities. J Phycol 48:1064-1078

> Harrold C, Reed DC (1985) Food availability, sea urchin grazing, and kelp forest community structure. Ecology 66:1160-1169

Hart MW, Scheibling RE (1988) Heat waves, baby booms, and the destruction of kelp beds by sea urchins. Mar Biol 99:167-176

> Hernández JC, Clemente S, Sangil C, Brito A (2008) Actual status of the sea urchin Diadema antillarum populations and macroalgal cover in marine protected areas compared to a highly fished area (Canary Islands-eastern Atlantic Ocean). Aquat Conserv 18:1091-1108

> Hernández JC, Clemente S, Girard D, Pérez-Ruzafa Á, Brito A (2010) Effect of temperature on settlement and postsettlement survival in a barrens-forming sea urchin. Mar Ecol Prog Ser 413:69-80

Himmelman JH (1986) Population biology of sea urchins on rocky barrens. Mar Ecol Prog Ser 33:295-306

Hjorleifsson E, Kassa O, Gunnarsson K (1995) Grazing of kelp by green sea urchins in Eyyjafjordu, North Iceland. In: Skjoldal HR, Hopkins C, Erikstad KK, Leinass HP (eds) Ecology of fjords and coastal waters. Elsevier, Amsterdam, p 593-597

Hobday AJ (2000) Persistence and transport of fauna on drifting kelp (Macrocystis pyrifera (L.) C. Agardh) rafts in the Southern California Bight. J Exp Mar Biol Ecol 253: 75-96

Hooper RG (1975) Bonne Bay marine resources. An ecological and biological assessment. Parks Canada, Halifax

Hop H, Pearson T, Hegseth EN, Kovacs KM, Wiencke C, 
Kwasniewski S, Gerland S (2002) The marine ecosystem of Kongsfjorden, Svalbard. Polar Res 21:167-208

> Huggett M, King C, Williamson JE, Steinberg P (2005) Larval development and metamorphosis of the Australian diadematid sea urchin Centrostephanus rodgersii. Invertebr Reprod Dev 47:197-204

Jackson JB (1997) Reefs since Columbus. Coral Reefs 16: S23-S32

Jamieson GS, Campbell A (1995) Red sea urchins and kelp in northern British Columbia. In: Skjoldal HR, Hopkins C, Erikstad KE, Leinaas HP (eds) Ecology of fjords and coastal waters. Elsevier Science, Amsterdam, p 537-547

- Johnson CR, Mann KH (1988) Diversity, patterns of adaptation, and stability of Nova Scotian kelp beds. Ecol Monogr 58:129-154

Johnson CR, Ling SD, Ross DJ, Shepherd S, Miller KJ (2005) Establishment of the long-spined sea urchin (Centrostephanus rodgersii) in Tasmania: first assessment of potential threats to fisheries. Project Report. School of Zoology and Tasmanian Aquaculture and Fisheries Institute, Hobart

> Johnson CR, Banks SC, Barrett NS, Cazassus F and others (2011) Climate change cascades: shifts in oceanography, species' ranges and subtidal marine community dynamics in eastern Tasmania. J Exp Mar Biol Ecol 400:17-32

> Johnson TR, Wilson JA, Cleaver C, Morehead G, Vadas R (2013) Modeling fine scale urchin and kelp dynamics: Implications for management of the Maine sea urchin fishery. Fish Res 141:107-117

Jones GM (1985) Paramoeba invadens n. sp. (Amoebida, Paramoebidae), a pathogenic amoeba from the sea urchin Strongylocentrotus droebachiensis in Eastern Canada. J Protozool 32:564-569

Jones NS, Kain JM (1967) Subtidal algal colonization following the removal of Echinus. Helgol Meeresunters 15: 460-466

Kannan K, Agusa T, Perrotta E, Thomas NJ, Tanabe S (2006) Comparison of trace element concentrations in livers of diseased, emaciated and non-diseased southern sea otters from the California coast. Chemosphere 65:2160-2167

Kawamata S (2010) Inhibitory effects of wave action on destructive grazing by sea urchins: a review. Bull Fish Res Agency 32:95-102

Keats DW (1991) Refugial Laminaria abundance and reduction in urchin grazing in communities in the Northwest Atlantic. J Mar Biol 71:867-876

Keats DW, South GR, Steele DH (1990) The effects of an experimental reduction in grazing by green sea urchins on a benthic macroalgal community in eastern Newfoundland. Mar Ecol Prog Ser 68:181-193

Kelly JR, Scheibling RE, Balch T (2011) Invasion-mediated shifts in the macrobenthic assemblage of a rocky subtidal ecosystem. Mar Ecol Prog Ser 437:69-78

Kitching JA (1987) Ecological studies at Lough Hyne. Adv Ecol Res 17:115-189

> Knowlton N (2004) Multiple 'stable' states and the conservation of marine ecosystems. Prog Oceanogr 60:387-396

Konar B (2000) Seasonal inhibitory effects of marine plants on sea urchins: structuring communities the algal way. Oecologia 125:208-217

Konar B, Estes JA (2003) The stability of boundary regions between kelp beds and deforested areas. Ecology 84: 174-185

Krause Jensen D, Marbà N, Olesen B, Sejr MK and others (2012) Seasonal sea ice cover as principal driver of spatial and temporal variation in depth extension and annual production of kelp in Greenland. Glob Change Biol 18:2981-2994

Krumhansl KA, Scheibling RE (2011) Detrital production in Nova Scotian kelp beds: patterns and processes. Mar Ecol Prog Ser 421:67-82

> Krumhansl KA, Scheibling RE (2012) Production and fate of kelp detritus. Mar Ecol Prog Ser 467:281-302

Lamb I, Zimmerman M (1964) Marine vegetation on Cape Anne, Essex County, Massachusetts. Rhodora 66:217-254

Lauzon-Guay JS, Scheibling RE (2007a) Seasonal variation in movement, aggregation and destructive grazing of the green sea urchin (Strongylocentrotus droebachiensis) in relation to wave action and sea temperature. Mar Biol 151:2109-2118

Lauzon-Guay JS, Scheibling RE (2007b) Behaviour of sea urchin Strongylocentrotus droebachiensis grazing fronts: food-mediated aggregation and density-dependent facilitation. Mar Ecol Prog Ser 329:191-204

> Lauzon-Guay JS, Scheibling RE (2007c) Importance of spatial population characteristics on the fertilization rates of sea urchins. Biol Bull 212:195-205

- Lauzon-Guay JS, Scheibling RE, Barbeau MA (2009) Modelling phase shifts in a rocky subtidal ecosystem. Mar Ecol Prog Ser 375:25-39

Lawrence JM (1975) On the relationships between marine plants and sea urchins. Oceanogr Mar Biol Annu Rev 13: 213-286

Lee RKS (1973) General ecology of the arctic benthic marine algae. Arctic 26:32-43

Lees K, Pitois S, Scott C, Frid C, Mackinson S (2006) Characterizing regime shifts in the marine environment. Fish Fish 7:104-127

Leinaas HP, Christie H (1996) Effects of removing sea urchins (Strongylocentrotus droebachiensis): stability of the barren state and succession of kelp forest recovery in the east Atlantic. Oecologia 105:524-536

> Leleu K, Remy-Zephir B, Grace R, Costello MJ (2012) Mapping habitats in a marine reserve showed how a 30 -year trophic cascade altered ecosystem structure. Biol Conserv 155:193-201

Levin PS (1994) Small-scale recruitment variation in a temperate fish: the roles of macrophytes and food supply. Environ Biol Fishes 40:271-281

Lewontin RC (1969) Meaning of stability. Brookhaven Symp Biol 22:13-24

Ling SD (2008) Range expansion of a habitat-modifying species leads to loss of taxonomic diversity: a new and impoverished reef state. Oecologia 156:883-894

> Ling SD, Johnson CR (2012) Marine reserves reduce risk of climate-driven phase shift by reinstating size-and habitat-specific trophic interactions. Ecol Appl 22:1232-1245

> Ling SD, Johnson CR, Frusher SD, Ridgeway KR (2009) Overfishing reduces resilience of kelp beds to climatedriven catastrophic phase shift. Proc Natl Acad Sci USA 106:22341-22345

Mann KH (1973) Seaweeds: their productivity and strategy for growth. Science 182:975-981

Marzloff MP, Johnson CR, Little LR, Soulie JC, Ling SD, Frusher SD (2013) Sensitivity analysis and patternoriented validation of TRITON, a model with alternative community states: insights on temperate rocky reefs dynamics. Ecol Model 258:16-32

Mathieson AC, Moore GE, Short FT (2010) A floristic comparison of seaweeds from James Bay and three contigu- 
ous Northeastern Canadian Arctic sites. Rhodora 112: 396-434

Matsunaga K, Kawaguchi T, Suzuki Y, Nigi G (1999) The role of terrestrial humic substances on the shift of kelp community to crustose coralline algae community of the southern Hokkaido Island in the Japan Sea. J Exp Mar Biol Ecol 241:193-205

> May RM (1977) Thresholds and breakpoints in ecosystems with a multiplicity of stable states. Nature 269:471-476

> McLean JH (1962) Sublittoral ecology of kelp beds of the open coast area near Carmel, California. Biol Bull 122: 95-114

McNaught DC (1999) The indirect effects of macroalgae and micropredation on the post-settlement success of the green sea urchin in Maine. PhD dissertation, University of Maine, Orono, ME

Meidel SK, Scheibling RE (1998) Annual reproductive cycle of the green sea urchin, Strongylocentrotus droebachiensis, in differing habitats in Nova Scotia, Canada. Mar Biol 131:461-478

Meidel SK, Scheibling RE (2001) Variation in egg spawning among subpopulations of sea urchins Strongylocentrotus droebachiensis: a theoretical approach. Mar Ecol Prog Ser 213:97-110

Mikhaylova TA (1999) The initial stages of experimental forming of Laminaria communities in the White Sea. Bot Zh 84:56-66

> Miller RJ (1985) Succession in sea urchin and seaweed abundance in Nova Scotia, Canada. Mar Biol 84:275-286

Miller RJ, Nolan SC (2000) Management of the Nova Scotia sea urchin fishery: a nearly successful habitat based management regime. Fisheries and Oceans Science, Canadian Stock Assessment Secretariat, Ottawa

Miner CM, Altstatt JM, Raimondi PT, Minchinton TE (2006) Recruitment failure and shifts in community structure following mass mortality limit recovery prospects of black abalone. Mar Ecol Prog Ser 327:107-117

Mohr JL, Wilimovsky NJ, Dawson EY (1957) An arctic Alaskan kelp bed. Arctic 10:45-52

Moore DS, Miller RJ (1983) Recovery of macroalgae following widespread sea urchin mortality with a description of the nearshore hard-bottom habitat on the Atlantic coast of Nova Scotia. Can Tech Rep Fish Aquat Sci 1230

Mumby PJ, Hastings A, Edwards HJ (2007) Thresholds and the resilience of Caribbean coral reefs. Nature 450:98-101

> Norderhaug KM, Christie HC (2009) Sea urchin grazing and kelp re-vegetation in the NE Atlantic. Mar Biol Res 5: 515-528

North WJ (1971) The biology of giant kelp beds (Macrocystis) in California: introduction and background. Nova Hedwigia 32:1-68

> Norton TA (1992) Dispersal by macroalgae. Br Phycol J 27:293-301

Oshurkov VV, Bazhin AG, Lukin VI, Sevostyanov VF (1988) Sea otter predation and the benthic community structure of Commander Islands. Biol Mora 6:50-60

Paine RT (1969) A note on trophic complexity and community stability. Am Nat 103:91-93

Pearce CM, Scheibling RE (1990) Induction of metamorphosis of larvae of the green sea urchin, Strongylocentrotus droebachiensis, by coralline red algae. Biol Bull 179: 304-331

Pearse JS, Hines AH (1979) Expansion of a central California kelp forest following the mass mortality of sea urchins. Mar Biol 51:83-91
Pearse JS, Clark ME, Leighton DL, Mitchell CT, North WJ (1970) Marine waste disposal and sea urchin ecology. In: North WJ (ed) Kelp Habitat Improvement Project, California Annual Report, 1969 to 1970. California Institute of Technology, Pasadena, CA, p 1-93

Pecorino D, Lamare MD, Barker MF (2012) Growth, morphometrics and size structure of the Diadematidae sea urchin Centrostephanus rodgersii in northern New Zealand. Mar Freshw Res 63:624-634

> Peterson CH (1984) Does a rigorous criterion for environmental identity preclude the existence of multiple stable points? Am Nat 124:127-133

Petraitis PS, Dudgeon SR (2004) Detection of alternative stable states in marine communities. J Exp Mar Biol Ecol 300:343-371

Petraitis PS, Latham RE (1999) The importance of scale in testing the origins of alternative community states. Ecology 80:429-442

Pinnegar JK, Polunin NVC, Francour P, Badalamenti F and others (2000) Trophic cascades in benthic marine ecosystems: lessons for fisheries and protected-area management. Environ Conserv 27:179-200

Propp MV (1977) Ecology of the sea urchin Strongylocentrotus droebachiensis of the Barents Sea: metabolism and regulation of abundance. Sov J Mar Biol 3:27-37

Raffaelli D, Hawkins S (1996) Intertidal ecology. Chapman \& Hall, London

Round FE (1967) The ecology of benthic algae. In: Jackson DE (ed) Algae and man. Plenum Press, New York, NY, p 138-184

Sala E, Boudouresque CF, Harmelin-Vivien M (1998) Fishing, trophic cascades and the structure of algal assemblages; evaluation of an old but untested paradigm. Oikos 82:425-439

Scheffer M, Carpenter S, Foley JA, Folke C, Walker B (2001) Catastrophic shifts in ecosystems. Nature 413:591-596

> Scheibling RE (1984) Echinoids, epizootics and ecological stability in the rocky subtidal off Nova Scotia, Canada. Helgol Meeresunters 37:233-242

Scheibling RE (1986) Increased macroalgal abundance following mass mortalities of sea urchins (Strongylocentrotus droebachiensis) along the Atlantic coast of Nova Scotia. Oecologia 68:186-198

Scheibling RE (1996) The role of predation in regulating sea urchin populations in eastern Canada. Oceanol Acta 19:421-430

> Scheibling RE, Hamm J (1991) Interactions between sea urchins (Strongylocentrotus droebachiensis) and their predators in field and laboratory experiments. Mar Biol 110:105-116

Scheibling RE, Lauzon-Guay JS (2010) Killer storms: North Atlantic hurricanes and disease outbreaks in sea urchins. Limnol Oceanogr 55:2331-2338

Scheibling RE, Hennigar AW, Balch T (1999) Destructive grazing, epiphytism, and disease: the dynamics of sea urchin-kelp interactions in Nova Scotia. Can J Fish Aquat Sci 56:2300-2314

Scheibling RE, Feehan CJ, Lauzon-Guay JS (in press) Climate change, disease and the dynamics of a kelp-bed ecosystem in Nova Scotia. In: Fernández-Palocios JM, Nascimiento LD, Hernández JC, Clement S, González A, Diaz-González JP (eds) Climate change: perspectives from the Atlantic: past, present and future. Servicio de Publicaciones de la Universidad de La Laguna, Tenerife, p 41-81 
Schiel DR (1990) Macroalgal assemblages in New Zealand: structure, interactions and demography. Hydrobiologia 192:59-76

Schiel DR, Andrew NL, Foster MS (1995) The structure of subtidal algal and invertebrate assemblages at the Chatham Islands, New Zealand. Mar Biol 123:355-367

Sharp G, Allard M, Lewis A, Semple R, Rochefort G (2008) The potential for seaweed resource development in subarctic Canada; Nunavik, Ungava Bay. J Appl Phycol 20: 491-498

Shears NT, Babcock RC (2003) Continuing trophic cascade effects after 25 years of no-take marine reserve protection. Mar Ecol Prog Ser 246:1-16

Shears NT, Babcock RC (2007) Quantitative description of mainland New Zealand's shallow subtidal reef communities. Science for Conservation 280, Department of Conservation, Wellington

Shears NT, Grace RV, Usmar NR, Kerr V, Babcock RC (2006) Long-term trends in lobster populations in a partially protected vs. no-take marine park. Biol Conserv 132: 222-231

Simenstad CA, Estes JA, Kenyon KW (1978) Aleuts, sea otters, and alternate stable-state communities. Science 200:403-411

Sivertsen K (1996) Incidence, occurrence and distribution of the nematode Echinomermella matsi in its echinoid host, Strongylocentrotus droebachiensis, in northern Norway. Mar Biol 126:703-714

Sivertsen K (1997) Geographic and environmental factors affecting the distribution of kelp beds and barren grounds and changes in biota associated with kelp reduction at sites along the Norwegian coast. Can J Fish Aquat Sci 54:2872-2887

Sivertsen K (2006) Overgrazing of kelp beds along the coast of Norway. J Appl Phycol 18:599-610

Sjøtun K, Fredriksen S, Rueness J (1998) Effect of canopy biomass and wave exposure on growth in Laminaria hyperborea (Laminariaceae: Phaeophyta). Eur J Phycol 33:337-434

Skadsheim A, Christie H, Leinaas HP (1995) Population reductions of Strongylocentrotus droebachiensis (Echinodermata) in Norway and the distribution of its endoparasite Echinomermella matsi (Nematoda). Mar Ecol Prog Ser 119:199-209

Steneck RS (1997) Fisheries-induced biological changes to the structure and function of the Gulf of Maine ecosystem In: Wallace GT, Braasch EF (eds) Proceedings of the Gulf of Maine Ecosystem Dynamics Scientific Symposium and Workshop. Regional Association for Research on the Gulf of Maine, Hanover, ME, p 151-165

Steneck RS, Dethier MN (1994) A functional group approach to the structure of algal-dominated communities. Oikos 69:476-498

Steneck RS, Graham MH, Bourque BJ, Corbett D, Erlandson JM, Estes JA, Tegner MJ (2002) Kelp forest ecosystems: biodiversity, stability, resilience and future. Environ Conserv 29:436-459

Steneck RS, Vavrinec J, Leland AV (2004) Accelerating trophic-level dysfunction in kelp forests ecosystems of the Western North Atlantic. Ecosystems 7:323-332

Steneck RS, Leland A, McNaught DC, Vavrinec J (2013) Ecosystem flips, locks, and feedbacks: the lasting effects of fisheries on Maine's kelp forest ecosystem. Bull Mar Sci 89:31-55
Sutherland JP (1974) Multiple stable points in natural communities. Am Nat 108:859-873

Tamaki H, Takahashi H, Fukaya A, Fukuda M, Arai S, Muraoka D (2005) The distributional patterns of Undaria pinnatifida (Harvey) Suringar and sea urchins related to water velocity condition in Ogatsu Bay, Miyagi Prefecture. Jpn J Phycol 53:131-135

Tamaki H, Kusaka K, Fukuda M, Arai S, Muraoka D (2009) Undaria pinnatifida habitat loss in relation to sea urchin grazing and water flow conditions, and their restoration effort in Ogatsu Bay, Japan. J Water Environ Technol 7:201-213

- Tegner MJ, Dayton PK (1981) Population structure, recruitment and mortality of two sea urchins (Strongylocentrotus franciscanus and $S$. purpuratus) in a kelp forest. Mar Ecol Prog Ser 5:255-268

> Tegner MJ, Dayton PK (1987) El Niño effects on southern California kelp forest communities. Adv Ecol Res 17: 243-279

> Tegner MJ, Dayton PK (1991) Sea urchins, El Niños, and the long term stability of Southern California kelp forest communities. Mar Ecol Prog Ser 77:49-63

> Tegner MJ, Dayton PK (2000) Ecosystem effects of fishing in kelp forest communities. ICES J Mar Sci 57:579-589

Tegner MJ, Dayton PK, Edwards PB, Riser KL (1996) Is there evidence for the long-term climatic change in southern California kelp forests? Calif Coop Ocean Fish Investig Rep 37:111-126

Tegner MJ, Dayton PK, Edwards PB, Riser KL (1997) Largescale, low-frequency oceanographic effects on kelp forest succession: a tale of two cohorts. Mar Ecol Prog Ser 146:117-134

> Thibaut T, Pinedo S, Torras X, Ballesteros E (2005) Longterm decline of the populations of Fucales (Cystoseira spp. and Sargassum spp.) in the Albères coast (France, North-western Mediterranean). Mar Pollut Bull 50: 1472-1489

> Trowbridge CD, Little C, Pilling GM, Stirling P, Miles A (2011) Decadal-scale changes in the shallow subtidal benthos of an Irish marine reserve. Bot Mar 54:497-506

> Tuya F, Sanchez-Jerez P, Haroun RJ (2005) Influence of fishing and functional group of algae on sea urchin control of algal communities in the eastern Atlantic. Mar Ecol Prog Ser 287:255-260

Vadas RL, Steneck RS (1988) Zonation of deep water benthic algae in the Gulf of Maine. J Phycol 24:338-346

Valentine JP, Johnson CR (2005) Persistence of sea urchin (Heliocidaris erythrogramma) barrens on the east coast of Tasmania: inhibition of macroalgal recovery in the absence of high densities of sea urchins. Bot Mar 48: 106-115

Vanderklift MA, Kendrick GA (2005) Contrasting influence of sea urchins on attached and drift macroalgae. Mar Ecol Prog Ser 299:101-110

Vásquez JA (1992) Lessonia trabeculata, a subtidal bottom kelp in northern Chile: a case study for a structural and geographical comparisons. In: Seeliger U (ed) Coastal plants of Latin America. Academic Press, San Diego, CA, p 77-89

Vásquez JA (2008) Production, use and fate of Chilean brown seaweeds: resources for a sustainable fishery. J Appl Phycol 20:457-467

Vásquez JA, Buschmann AH (1997) Herbivore-kelp interactions in Chilean subtidal communities: a review. Rev Chil Hist Nat 70:41-52 
Vásquez JA, Castilla JC, Santelices B (1984) Distributional patterns and diets of four species of sea urchins in giant kelp forest (Macrocystis pyrifera) of Puerto Toro, Navarino Island, Chile. Mar Ecol Prog Ser 19:55-63

Vásquez JA, Vega JA, Buschmann AH (2006) Long term variability in the structure of kelp communities in northern Chile and the 1997-98 ENSO. J Appl Phycol 18: 505-519

Vega JMA, Vasquez JA, Buschmann AH (2005) Population biology of the subtidal kelps Macrocystis integrifolia and Lessonia trabeculata (Laminariales: Phaeophyta) in an upwelling ecosystem of northern Chile: interannual variability and El Niño 1997-98. Rev Chil Hist Nat 78:33-50

Watanuki A, Aota T, Otsuka E, Kawai T, Iwahashi Y, Kuwahara H, Fujita D (2010) Restoration of kelp beds on an urchin barren: Removal of sea urchins by citizen divers in southwestern Hokkaido. Bull Fish Res Agency 32: 83-87

Watson J, Estes JA (2011) Stability, resilience, and phase shifts in rocky subtidal communities along the west coast of Vancouver Island, Canada. Ecol Monogr 81:215-239

Wernberg T, Russell BD, Moore PJ, Ling SD and others (2011) Impacts of climate change in a global hotspot for temperate marine biodiversity and ocean warming. J Exp Mar Biol Ecol 400:7-16

Wharton WG (1980) The distribution of sea urchindominated barren grounds along the south shore of Nova Scotia. Can Tech Rep Fish Aquat Sci 954:33-47

Wharton WG, Mann KH (1981) Relationship between destructive grazing by the sea urchin, Strongylocentrotus droebachiensis, and the abundance of American lobster, Homarus americanus, on the Atlantic coast of Nova Scotia. Can J Fish Aquat Sci 38:1339-1349

Wiencke CM, Clayton N, Gómez I, Iken K and others (2007) Life strategy, ecophysiology and ecology of seaweeds in polar waters. In: Amils R, Ellis-Evans C, HinghoferSzalkay HG (eds) Life in extreme environments. Springer, Dordrecht, p 213-244

Wilce RT, Pedersen PM, Sekida S (2009) Chukchia pedicellata gen. et sp. nov. and C. endophyticanov. comb., Arctic endemic brown algae (Phaeophyceae). J Phycol 45:272-286

Wilmers CC, Estes JA, Edwards M, Laidre KL, Konar B (2012) Do trophic cascades affect the storage and flux of atmospheric carbon? An analysis of sea otters and kelp forests. Front Ecol Environ 10:409-415

Appendix. Documented kelp beds in the Beaufort Sea, Canadian Arctic, Greenland and northern Europe

\begin{tabular}{|llc|}
\hline Region & Kelp species & Source \\
\hline Alaska, USA & & Dunton et al. (1982) \\
Stefensson Sound & Laminaria solidungula, Saccharina latissima & Wiencke et al. (2007) \\
Demarcation Point & L. solidungula, S. latissima & Wiencke et al. (2007) \\
Camdem Bay & L. solidungula, S. latissima & Mohr et al. (1957) \\
Chukchi Sea & L. solidungula, S. latissima & Wiencke et al. (2007) \\
Prince Patrick Island & S. latissima & Wilce et al. (2009) \\
Canadian Arctic & & Cross et al. (1987) \\
Bylot Island & S. latissima & Cross et al. (1987) \\
Cape Hatt & S. latissima, Alaria esculenta & Lee (1973) \\
Pangnirtung Fiord & Laminaria sp. & Sharp et al. (2008) \\
Brock Island & L. solidungula & Cross et al. (1987) \\
Ungava Bay & A. esculenta, L. solidungula, L. digitata, S. latissima & Chapman \& Lindley (1981) \\
Lancaster South & A. esculenta, L. solidungula, S. groenlandica, S. latissima & Mathieson et al. (2010) \\
Foxe Basin & A. esculenta, L. solidungula, S. groenlandica, S. latissima & \\
Hudson Bay & A. esculenta, L. solidungula, L. digitata, S. latissima & Krause-Jensen et al. (2012) \\
Greenland & & Bischoff \& Wiencke (1993) \\
Siorapoluk to Nuuk & S. latissima, Agarum clathratum, L. solidungula & Glud et al. (2009) \\
Disko Island & S. latissima & \\
Young Sound & S. latissima & Hop et al. (2002) \\
Northern Europe & & \\
Svalbard & L. digitata, L. solidungula, S. latissima, A. esculenta, Saccorhiza & Wiencke et al. (2007) \\
Kingsfjorden & dermatodea & Mikhaylova (1999) \\
White Sea & L. digitata, L. solidungula, S. latissima, A. esculenta, S. dermatodea & L. digitata, L. hyperborea, S. latissima, A. esculenta, S. dermatodea \\
\hline
\end{tabular}

